AUTARQUIA ASSOCIADA À UNIVERSIDADE DE SÃO PAULO

\title{
ESTUDO IN VITRO DOS EFEITOS DA RADIAÇÃO IONIZANTE EM TECIDO ÓSSEO POR ESPECTROSCOPIA VIBRACIONAL
}

\author{
DERLY AUGUSTO DIAS
}

Dissertação apresentada como parte dos requisitos para obtenção do Grau de Mestre em Ciências na Área de Tecnologia Nuclear - Materiais

Orientadora:

Profa. Dra. Denise Maria Zezell

São Paulo 
INSTITUTO DE PESQUISAS ENERGÉTICAS E NUCLEARES

Autarquia associada à Universidade de São Paulo

\section{ESTUDO IN VITRO DOS EFEITOS DA RADIAÇÃO IONIZANTE EM TECIDO ÓSSEO POR ESPECTROSCOPIA VIBRACIONAL}

\section{DERLY AUGUSTO DIAS}

Dissertação apresentada como parte dos
requisitos para obtenção do Grau de
Mestre em Ciências na Área
de Tecnologia Nuclear-Materiais

Orientadora:

Profa. Dra. Denise Maria Zezell

Versão Corrigida

Versão Original disponível no IPEN

São Paulo

2018 
Fonte de Financiamento: CEPID/FAFESP 05/51689-2, INCT/CNPq 465763/2014-6, CNPq 830615/1999-7 e CAPES/PROCAD 88881.068505/2014-01

Autorizo a reprodução e divulgação total ou parcial deste trabalho, para fins de estudo e pesquisa, desde que citada a fonte

Como citar:

AUGUSTO DIAS, D. . ESTUDO IN VITRO DOS EFEITOS DA RADIAÇÃO IONIZANT EM TECIDO ÓSSEO POR ESPECTROSCOPIA VIBRACIONAL. 2018. 69 p. Dissertação (Mestrado em Tecnologia Nuclear), Instituto de Pesquisas Energéticas e Nucleares, IPEN-CNEN/SP, São Paulo. Disponível em: <www.teses.usp.br> (data de consulta no formato: $\mathrm{dd} / \mathrm{mm} / \mathrm{aaaa}$ )

Ficha catalográfica elaborada pelo Sistema de geração automática da Biblioteca IPEN/USP, com os dados fornecidos pelo(a) autor(a)

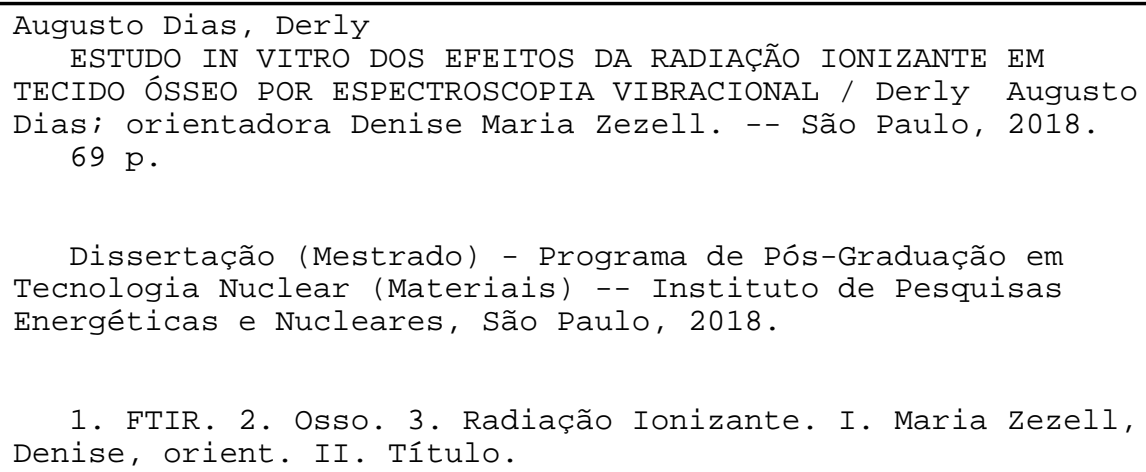




\section{DEDICATÓRIA}

A minha avó Lourdes e meu tio Jorge que em algum lugar estão olhando e cuidando de mim. 


\section{AGRADECIMENTOS}

A Letícia, minha namorada, que sempre esteve ao meu lado, me ajudou nos momentos mais difíceis que passei durante essa etapa, por entender e suportar essa distância durante esses 2 anos, o que com certeza me fortaleceu e me deixou mais confiante.

À minha orientadora Professora Doutora Denise Maria Zezell pelos ensinamentos, paciência, conselhos e por acreditar no meu potencial.

Aos meus companheiros do Laboratório de Biofotônica, Daísa, Gabriela, Márcia, Lúcia, Susi, Mônica, Nath, pela paciência em passar os seus conhecimentos com clareza e pela amizade.

À Cacau por toda ajuda durante todo o trabalho, me acompanhando desde a parte experimental, até a conclusão deste trabalho.

Ao Pedro, pela amizade, conversas, apoio e pela ajuda essencial no desenvolvimento deste trabalho.

A minha amiga Jéssica, pelas conversas e por me acolher durante os primeiros meses de mestrado.

Ao Cássio por todas as orientações e pelas conversas, que me ajudaram muito no desenvolvimento deste trabalho.

A minha família por todo suporte e força que me deram.

A minha mãe que sempre me apoiou, conversou, incentivou e principalmente pela paciência que teve comigo, durante toda essa jornada.

Ao Instituto de Pesquisas Energéticas e Nucleares (IPEN), pela estrutura e pela bolsa fornecida. 
O sucesso é ir de fracasso em fracasso sem perder o entusiasmo.

Winston Churchill 


\section{RESUMO}

DIAS, Derly. A. ESTUDO IN VITRO DOS EFEITOS DA RADIAÇÃO IONIZANTE EM TECIDO ÓSSEO POR ESPECTROSCOPIA VIBRACIONAL. 2018. Dissertação (Mestrado em Tecnologia Nuclear) - Instituto de Pesquisas Energéticas e Nucleares - IPEN-CNEN/SP. São Paulo

O tecido ósseo fornece sustentação e estrutura ao corpo, serve de alavanca para a função motora dos músculos esqueléticos, protege os órgãos internos, tem papel fundamental na fisiologia e está sujeito aos efeitos danosos da radiação ionizante. A estimativa para o Brasil, biênio 2016-2017, aponta a ocorrência de cerca de 600 mil casos novos de câncer e cerca de 8.000 solicitações de tecido ósseo para enxerto. Neste sentido a caracterização do tecido ósseo irradiado, através de técnicas de espectroscopia vibracional, pode ser uma importante ferramenta para compreender quais componentes são afetados e o quanto as diferentes doses de radiação ionizante alteram sua estrutura molecular. A técnica de espectroscopia ATR-FTIR (Attenuated Total Reflection - Fourier Transform Infrared Spectroscopy), que permite análises qualitativas e semi-quantitativas, foi utilizada para caracterizar o tecido ósseo. Foram coletadas 110 amostras de diferentes fêmures bovinos e irradiadas com doses de 0,002 kGy; 0,004 kGy; 0,07 kGy; 1 kGy, 10 kGy, 15 kGy, 25 kGy, 35 kGy, 50 kGy e 60 kGy em fonte de ${ }^{60}$ Co. A espectroscopia ATR-FTIR demonstrou-se eficaz na caracterização do tecido e é possível afirmar que a radiação ionizante alterou a estrutura bioquímica do tecido ósseo, em sua matriz orgânica independente da dose aplicada e inorgânica a partir de 10 kGy.

Palavras Chave: FTIR, Osso, Radiação lonizante. 


\begin{abstract}
DIAS, Derly. A. IN VITRO STUDY OF THE EFFECTS OF IONIZING RADIATION IN BONE TISSUE BY VIBRATIONAL SPECTROSCOPY. 2018. Dissertação (Mestrado em Tecnologia Nuclear) - Instituto de Pesquisas Energéticas e Nucleares - IPEN-CNEN/SP. São Paulo
\end{abstract}

Bone tissue provides support and structure to the body, function at the skeletal system providing muscle function, protects vital internal organs, plays a key role in physiology, and is subject to the damaging effects of radiation. The estimate for Brazil, biennium 2016-2017, indicates the occurrence of about 600 thousand new cases of cancer and about 8,000 requests of bone tissue for grafting. In this sense, the characterization of the irradiated bone tissue by means of vibrational spectroscopy techniques can be an important tool to understand which components are affected and how different doses of ionizing radiation alter their molecular structure. The ATR-FTIR (Attenuated Total Reflection) spectroscopy technique, which allows qualitative and semi-quantitative analyzes, was used to characterize bone tissue. A total of 110 samples of different bovine femurs were collected and irradiated at doses of 0.002 kGy; 0.004 kGy; 0.07 kGy; 1 kGy, 10 kGy, 15 kGy, 25 kGy, 35 kGy, 50 kGy and 60 kGy in ${ }^{60} \mathrm{Co}$ source. ATRFTIR spectroscopy proved to be effective in tissue characterization and it is possible to state that ionizing radiation altered the biochemical structure of the bone tissue in its organic matrix independent of the applied and inorganic dose from $10 \mathrm{kGy}$.

Keywords: FTIR, Bone, lonizing Radiation. 


\section{SUMÁRIO}

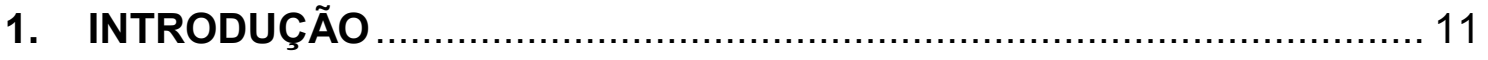

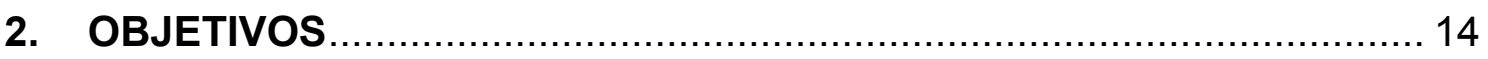

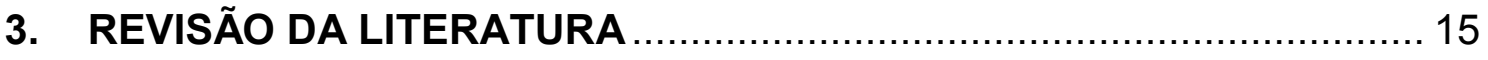

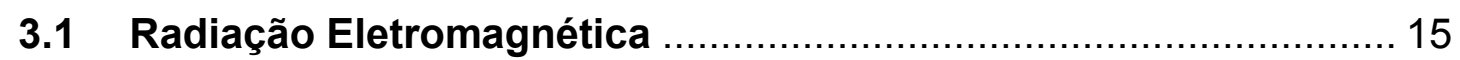

3.2 Radiação Eletromagnética lonizante e sua interação com a matéria 17

3.3 Efeitos Biológicos da Radiação lonizante ................................ 19

3.4 Espectroscopia no Infravermelho......................................... 22

3.4.1 Acessório de Reflexão Total Atenuada (ATR) .......................... 25

3.5 FTIR em Tecidos Mineralizados ............................................ 26

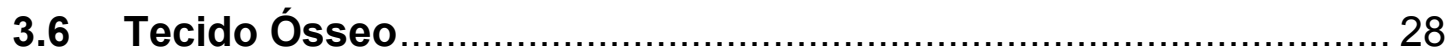

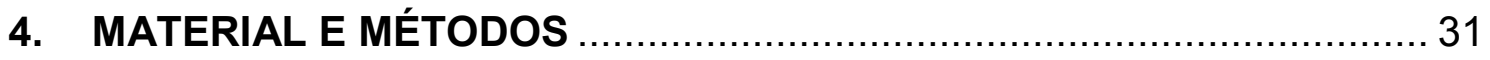

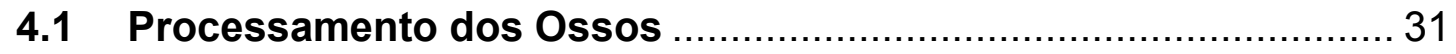

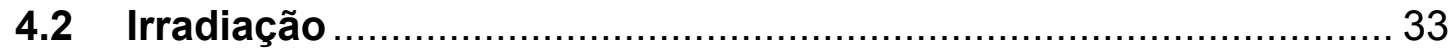

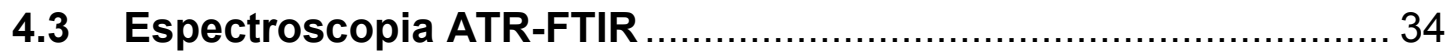

4.4 Forma de análise de resultados ........................................... 36

4.4.1 Pré-processamento dos dados ............................................. 36

4.4.1.1 Normalização vetorial ............................................ 37

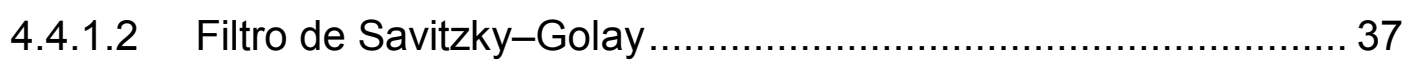

4.4.1 Análise de componentes principais (PCA) ........................... 37

4.4.2 Análise discriminante Linear (LDA) ..................................... 38

4.4.3 Cálculo de Área sobre as bandas de interesse ........................ 38

4.4.4 Análise de Cristalinidade ................................................... 39

4.4.5 Razão das áreas de Amida I + Amida II / Fosfato. ..................... 40

4.4 .6 Estatística ............................................................... 40

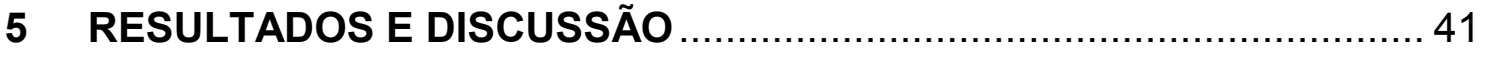

5.1 Análise de Componentes Principais (PCA/LDA) ...................... 43

5.2 Área sob a curva da banda de Fosfato $v 1, v 3 \mathbf{P O}_{4}{ }^{3-} \ldots \ldots \ldots \ldots \ldots \ldots \ldots . . \ldots 6$ 
5.3 Área sob a curva da banda de Amida I........................................ 48

5.4 Área sob a curva da banda de Amida II........................................ 50

5.5 Área sob a curva da banda de Amida III..................................... 52

5.6 Área sob a curva da banda de Colágeno ……............................. 54

5.7 Área sob a curva da banda de Carbonato ....................................... 56

5.8 Análise de Índice de Cristalinidade .......................................... 58

5.9 Razão da área de Amida I + Amida II/Fosfato …............................ 60

5.10 Razão da área de Carbonato/Fosfato ......................................... 62

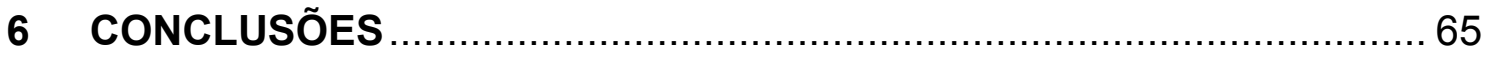

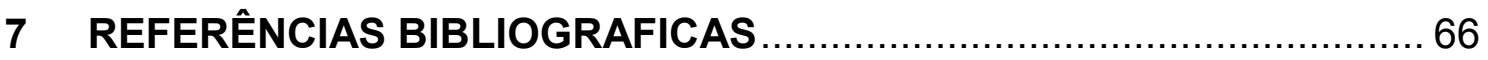

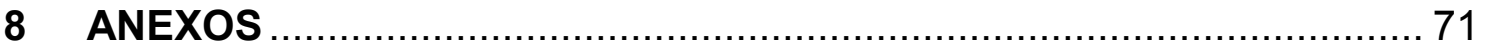





\section{INTRODUÇÃO}

Com a evolução do estudo das aplicações da radiação ionizante, progrediram também as pesquisas em relação aos efeitos provocados no corpo humano e sua interação nos tecidos biológicos. Foram desenvolvidos métodos de utilização, controle e proteção da radiação ionizante, de forma que, existem órgãos reguladores para controlar o uso da energia nuclear. Dentre estes órgãos está a Comissão Nacional de Energia Nuclear (CNEN). A radiação ionizante é amplamente utilizada em vários segmentos, no setor industrial na descontaminação de alimentos, na ciência com a finalidade de promover o estudo da organização atômica e molecular de outros elementos, na área da saúde com a esterilização de materiais cirúrgicos e com destaque para esterilização de tecido ósseo para enxerto e radioterapia para tratamento de câncer.

Os processos biológicos de resposta dos sistemas do corpo humano à radiação ionizante permanecem não totalmente esclarecidos para os pesquisadores. O sistema esquelético humano não é exceção. $O$ tecido ósseo fornece sustentação e estrutura ao corpo, serve de alavanca para a função motora dos músculos esqueléticos, protege os órgãos internos e tem papel fundamental na fisiologia humana. O tecido ósseo é parte de um sistema complexo com muitas variáveis que afetam sua composição, sua formação, força e propriedades mecânicas. Este sistema constitui-se de uma variedade de tecido conjuntivo de propriedade especial, com matriz calcificada, onde a presença de fosfato de cálcio confere ao tecido a propriedade mecânica de dureza. Estes componentes inorgânicos na forma de hidroxiapatita formam uma matriz que está envolta em fibras colágenas. Estão inseridas nesta matriz mista diversas células ósseas: osteoblastos, osteócitos e osteoclastos. Os osteoblastos são células de citoplasma volumoso e grande função metabólica tendo por função a formação da matriz tecidual; o osteócito é uma célula originada do osteoblasto pelo aprisionamento celular durante a síntese da matriz óssea. De morfologia "em estrela" com prolongamentos citoplasmáticos que se comunicam e é responsável pela distribuição da nutrição e manutenção do tecido e; por fim, o osteoclasto, uma célula com membrana plasmática com microvilosidades que aumentam sua área de superfície facilitando a função de reabsorção e 
remodelação do tecido ósseo. O Cálcio e do Fósforo presentes na matriz óssea são armazenados na medula óssea no interior de ossos longos (fêmur, tíbia, fíbula, rádio, ulna) que são aqueles que, por definição, tem comprimento maior que largura e largura e espessura semelhantes. As estruturas típicas de um osso longo são diáfise, epífise e metáfise. A diáfise é o longo eixo do osso compacto circundando uma cavidade medular central preenchida com medula óssea. As epífises são superfícies articulares cobertas com cartilagem hialina e as linhas epifiseais separam diáfise de epífise. A metáfise é a região de ligação física entre diáfise e epífise. Os ossos são revestidos em sua parte externa pelo periósteo que é uma membrana dupla que contem nervos e vasos sanguíneos e na parte interna pela medula óssea ${ }^{1,2}$.

Com relação à interação da radiação ionizante com o complexo tecido ósseo, os processos macroscópicos que são facilmente observados têm origem em processos microscópicos ou moleculares que não foram totalmente esclarecidos. A radiação ionizante afeta as principais propriedades mecânicas e biológicas do tecido ósseo, degradando o colágeno da matriz óssea. Especificamente, os raios gama possuem energia de fóton capaz de romper as cadeias de polipeptídios. Em amostras úmidas, a irradiação causa a liberação de radicais livres por radiólise de moléculas de água que causam a quebra das ligações cruzadas de colágeno. Estes efeitos são dose dependente ${ }^{1}$. Muitos métodos utilizados para estudar o tecido ósseo foram inadequados para explorar completamente todas as interações que ocorrem em um sistema tão dinâmico. Além disso, a maioria desses métodos não é capaz de fornecer informações em nível molecular. Com a evolução de métodos de análise estatística multivariada, avaliação de componentes principais e possibilidade de imageamento espectral, a espectroscopia vibracional por absorção no infravermelho e espalhamento Raman, têm sido empregadas por um número crescente de pesquisadores no estudo do tecido ósseo ${ }^{3}$.

A estimativa para o Brasil, biênio 2016-2017, aponta a ocorrência de cerca de 600 mil casos novos de câncer. Em um país situado em região de trópico com alta incidência de luz solar, são mais abundantes casos de câncer do sistema tegumentar (pele e anexos). Excetuando-se o câncer de pele não melanoma (aproximadamente 180 mil casos novos), ocorrerão cerca de 420 mil casos 
novos de câncer no período citado ${ }^{4}$. No tratamento de combate ao câncer, a radioterapia utiliza a dose habitual, na região da cabeça e pescoço, de 50 a 70 Gy ( 0.05 a $0.07 \mathrm{kGy})$ fracionadas em até 7 semanas com uma dose diária de 2 Gy $(0.002 \mathrm{kGy})^{5}$. Este protocolo varia de acordo com a classificação da patologia a ser tratada, avaliação médica, condições sistêmicas e idade do paciente, entre outras variáveis. As características minerais, como o tamanho e a perfeição do cristal de hidroxiapatita, o teor de fosfato e de carbonato podem ser substancialmente alterados em função do tipo de tecido, idade, patologia ou tratamento proposto que acometem o tecido ósseo. Entretanto, independente da dose utilizada, a radiação ionizante sempre apresentará interação com o tecido ósseo mesmo que este não seja o tecido alvo do tratamento oncológico. Segundo o levantamento da Associação Brasileira de Transplante de Órgãos, foram realizados 15.429 transplantes de tecidos entre Janeiro e Junho de 2017, sendo que 7.520 casos foram de tecido ósseo ${ }^{6}$. Neste caso também é utilizada a radiação ionizante em tecido ósseo com a finalidade de esterilização do tecido doador, diminuindo o risco de contaminação do paciente ao enxerto. Para esterilização de tecidos ósseos a serem utilizados para enxerto, também denominados aloenxertos, normalmente é utilizada dose de $25 \mathrm{kGy}$ a $60 \mathrm{kGy}$. A caracterização do tecido ósseo irradiado pode contribuir na compreensão de quais componentes biológicos são especificadamente afetados e como as diferentes doses de radiação contribuem nas alterações de suas propriedades moleculares. Atualmente utiliza-se a técnica de EPR (Electron Paramagnetic Resonance), no entanto, trata-se de uma técnica invasiva, tendo em vista que há a necessidade de separar o material orgânico da estrutura da hidroxiapatita do tecido ósseo e normalmente é realizada a partir da retirada de um fragmento ósseo da costela do paciente ou dente ${ }^{8}$. Desta maneira, torna-se explicita a importância da caracterização do tecido ósseo por técnicas não invasivas. 


\section{OBJETIVOS}

O objetivo deste estudo foi avaliar as mudanças moleculares no tecido ósseo em função de diferentes doses de radiação ionizante, por meio da técnica de análise de espectroscopia de absorção no infravermelho por transformada de Fourier. 


\section{REVISÃO DA LITERATURA}

\subsection{Radiação Eletromagnética}

A energia eletromagnética é emitida por qualquer corpo que possua temperatura acima de zero absoluto (0 Kelvin). Assim, todo corpo com temperatura absoluta acima de zero pode ser considerado como uma fonte de energia eletromagnética. O Sol e a Terra são as duas principais fontes naturais de energia eletromagnética utilizadas no sensoriamento remoto da superfície terrestre ${ }^{9}$.

A energia eletromagnética não precisa de um meio material para se propagar, sendo definida como uma energia que se move na forma de ondas eletromagnéticas à velocidade da luz $(300.000 \mathrm{~km} / \mathrm{s})$. Dado que a velocidade de propagação das ondas eletromagnéticas é diretamente proporcional à sua frequência e comprimento de onda, esta pode ser expressa pela equação 1

$$
c=f \cdot \lambda
$$

Onde $c$ é a velocidade da luz (299 $792458 \mathrm{~m} / \mathrm{s}), f$ é a frequência em ciclos/s ou $\mathrm{Hz}$ e $\lambda$ é o comprimento de onda $(\mathrm{m})$.

Sob uma perspectiva ondulatória, se propaga na forma de ondas formadas pela oscilação dos campos elétrico e magnético. Enquanto que sob uma perspectiva quântica, a radiação eletromagnética é concebida como o resultado da emissão de pequenos pulsos de energia conhecidos como quanta inicialmente proposta por Plank e posteriormente adotada no estudo do efeito fotoelétrico entre 1905 e 1917 por Albert Einsten que propôs que a radiação era composta por uma coleção de partículas indivisíveis que carregavam energia hv e momento hv/c em uma direção definida, e que tais grandezas seriam conservadas no processo de interação da radiação com a matéria, a energia contida de um fóton é calculada pela equação $2^{10}$.

$$
E=h v=\frac{c}{\lambda}
$$

Onde $h$ é a constante de Plank $(6,626 \times 10-34 \mathrm{~J} . s), v$ é a frequência da radiação em Hertz, $c$ é a velocidade da luz no vácuo $(3 \times 108 \mathrm{~m} / \mathrm{s})$ e $\lambda$ é o 
comprimento de onda. A partir da equação 2, é possível concluir que quanto maior a frequência ou quanto menor o comprimento de onda, maior será a energia de um fóton, considerando a velocidade constante. A Figura 1 apresenta um esquema da representação dos campos elétrico e magnético e as oscilações mencionadas.

Figura 1 - Propagação de uma onda eletromagnética

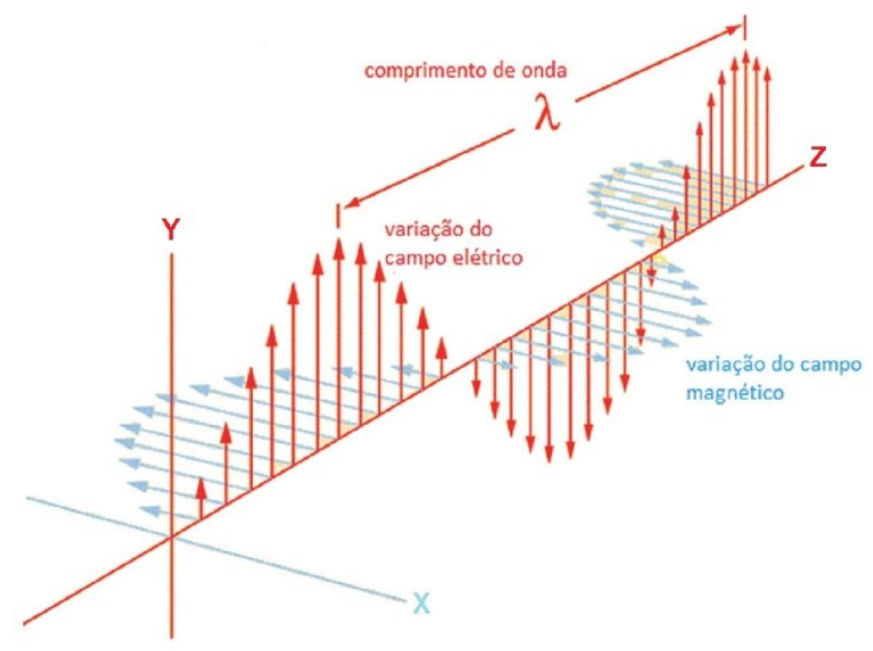

Fonte - adaptado de Luz para o progresso do conhecimento e suporte da vida ${ }^{11}$

No modelo ondulatório então, a radiação eletromagnética é caracterizada em comprimentos de onda que representam a distância entre dois pontos de igual intensidade dos campos elétrico e magnético. O conjunto de comprimentos de onda que compõem a radiação eletromagnética é conhecido como Espectro Eletromagnético (Figura 2). 
Figura 2 - Espectro eletromagnético.

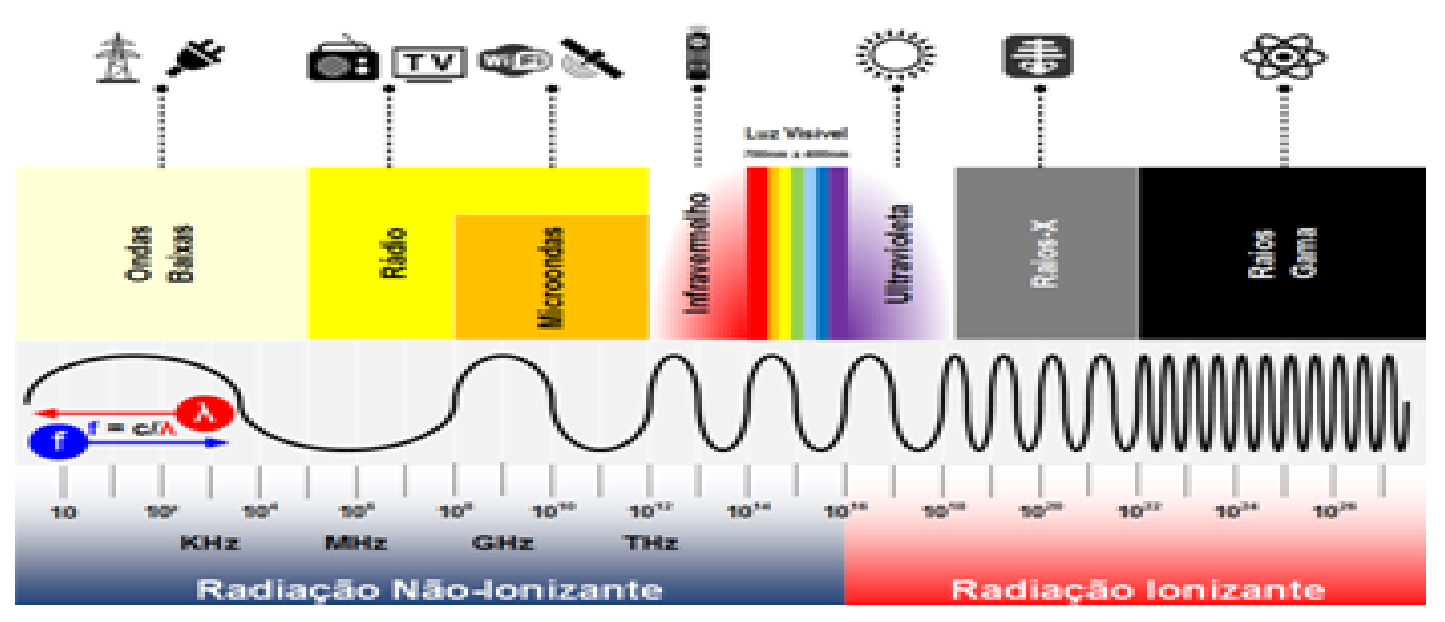

Fonte - O Espectro Eletromagnético na Natureza ${ }^{12}$

A intensidade da radiação / pode ser definida pelo número de fótons $N$, multiplicado pela energia de cada fóton $h v$, dividido por unidade de tempo $t \mathrm{e}$ unidade de área $A$ como observado na equação 3.

$$
I=\frac{N \cdot h v}{A \cdot t}
$$

\subsection{Radiação Eletromagnética Ionizante e sua interação com a matéria}

O termo radiação ionizante refere-se a toda radiação capaz de causar ejeção de elétrons dos orbitais de átomos ou moléculas, é capaz de gerar íons pelo deslocamento de elétrons de moléculas e átomos de forma direta e indireta. Os íons e elétrons formados são capazes de gerar radicais livres altamente reativos, que podem desencadear reações químicas com outros compostos ou entre si podendo levar a alterações nas propriedades físicas e químicas dos materiais ${ }^{13}$. As radiações ionizantes estão presentes no cotidiano, sendo parte de diversos processos analíticos na indústria e na medicina. Para que estes fenômenos possam ser utilizados em benefício da humanidade e em condições adequadas de segurança, é muito importante o conhecimento dos processos de interação da radiação com a matéria e das diferentes formas de detecção.

As partículas carregadas, como elétrons, prótons e partículas- $\alpha$, são conhecidas como radiação ionizante direta, desde que tenham energia cinética suficiente para produzir ionização por colisão. O processo de colisão é uma 
interação entre os campos eletromagnéticos associados à partícula colidindo e ao elétron orbital. $O$ contato físico real entre as partículas não é necessário, à medida que penetram a matéria. As partículas não carregadas, como os nêutrons e os fótons, são radiações ionizantes indiretas, porque libertam partículas ionizantes quando interagem com a matéria. Os fótons ionizantes interagem com os átomos de um material para produzir elétrons de alta velocidade por três processos principais: efeito fotoelétrico, efeito Compton e produção de pares, apresentados na Figura $3{ }^{14}$.

Figura 3 (A) Efeito Fotoelétrico, (B) Efeito Compton e (C) Produção de pares

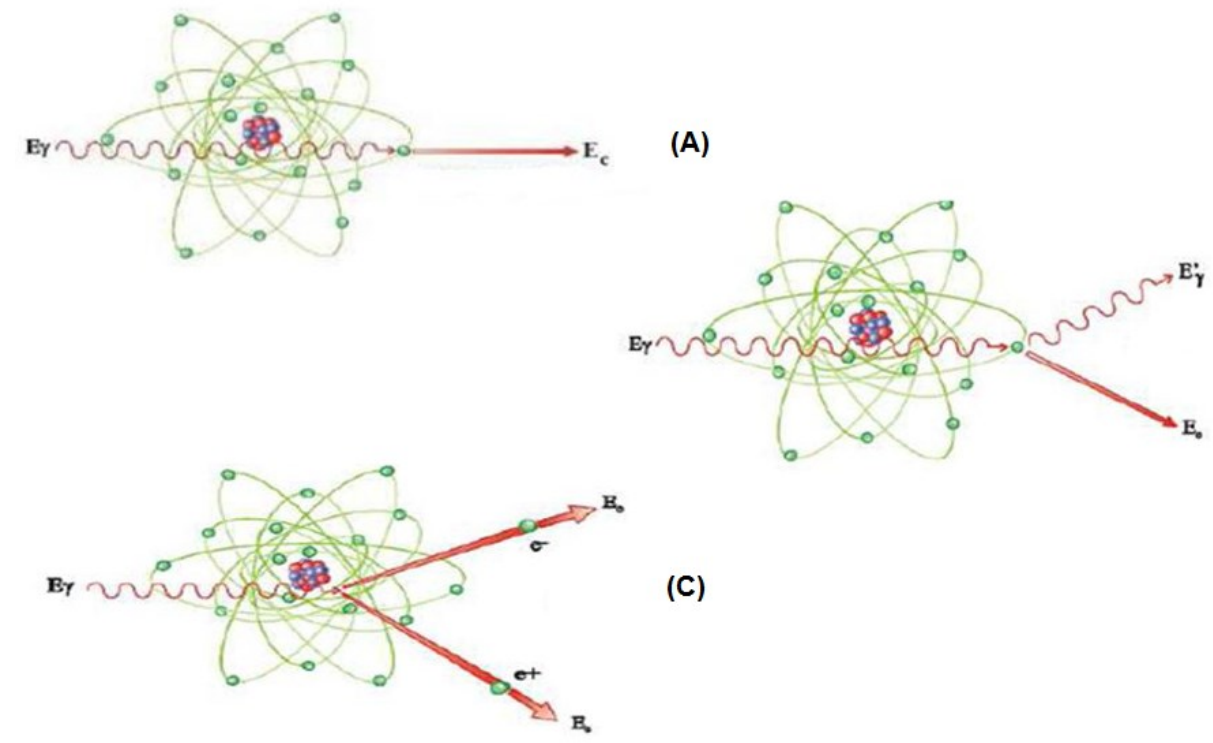

(B)

Fonte - Adaptado de Medicina Nuclear ${ }^{15}$

No efeito fotoelétrico $(A)$, um fóton é totalmente absorvido por um átomo. No seu lugar, um fotoelétron rápido é ejetado do átomo. A interação acontece com o átomo como um todo e não pode ocorrer com elétrons livres. A energia do fotoelétron $E_{\mathrm{e}}$ é dada por:

$$
E_{e}=h v-E_{b}
$$

Onde $E_{b}$ é a energia de ligação do elétron e $h v$ é a energia do fóton. Para raios gama com energias acima de algumas dezenas de $\mathrm{keV}$, o fotoelétron leva consigo a maioria da energia do fóton. A interação também cria um íon no material absorvedor com uma vacância em uma de suas camadas. Em geral, esta vacância é rapidamente preenchida com a captura de um elétron livre do meio e/ou por rearranjo de outros elétrons do átomo. 
No Efeito Compton (B), a interação acontece entre o fóton incidente e o elétron no material absorvedor. O fóton incidente transfere parte de sua energia para o elétron, é então espalhado em um ângulo $\theta$ com respeito a sua direção inicial. Devido ao fato que todos os ângulos de espalhamento são possíveis, a energia transferida para o elétron pode variar de zero até uma fração significativa do fóton incidente. Na faixa de energia dos raios gama, o espalhamento Compton é o mecanismo dominante.

Produção de pares $(C)$ é o processo que resulta na conversão de um fóton em um par elétron-pósitron. Como o fóton não possui massa, enquanto o pósitron e o elétron possuem, dizemos que este processo converte energia em massa de acordo com a relação $E=m c^{2}$.

\subsection{Efeitos Biológicos da Radiação lonizante}

Os efeitos biológicos das diferentes radiações dependem não apenas da dose administrada, mas também da distribuição microscópica da dose, expressa em termos de transferência linear de energia (LET ou linear energy transfer). Densamente, as radiações ionizantes, como nêutrons, e íons pesados, são radiações LET altas, enquanto os fótons, os elétrons e os prótons de alta energia são radiações baixas. Quanto maior o LET, maior o efeito biológico de um dado tipo de radiação. Quanto menor a energia cinética de uma radiação particular, maior é a LET e, portanto, seu efeito biológico. Os íons, portanto, têm valores LET mais altos perto do final de seu intervalo ${ }^{16}$. A radiação pode agir por mecanismos diretos e indiretos. Efeitos diretos causam colisões diretas da radiação ionizante com as moléculas podendo gerar danos irreversíveis ao DNA e a proteínas como o colágeno, conforme ilustrado na Figura 4. Efeitos indiretos ocorrem quando a radiação interage com moléculas de água, quebrando-a e produzindo íons e radicais livres. A esse fenômeno se dá o nome de radiólise (vide equação 5). Os íons são espécies químicas que possuem carga e número par de elétrons. Os radicais livres são altamente reativos. Sendo formas altamente reativas, originados em decorrência da radiólise da água, interagem quimicamente entre si ou com moléculas próximas a eles. Como consequência, novas moléculas podem ser danificadas, passando a disputar elétrons com o meio. 


$$
\mathrm{H}_{2} \mathrm{O}+h v \rightarrow \mathrm{H}_{2} \dot{O}^{+}+e^{-} \rightarrow \dot{H}+H \dot{O}
$$

Figura 4 - Efeitos diretos e indiretos da radiação ionizante

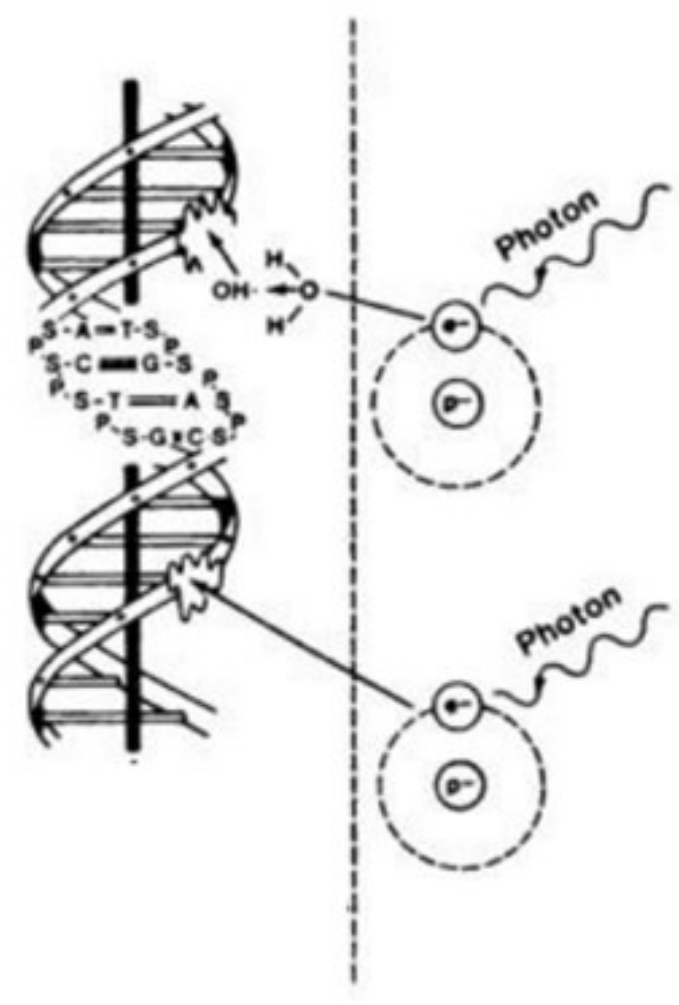

Fonte: Physics in Medicine Week 3: Radiotherapy ${ }^{17}$

Sendo a mais abundante em um organismo biológico, a molécula de água participa praticamente de todas as reações metabólicas em um organismo. Nos humanos, cerca de 70 a $75 \%$ do corpo, o que reflete a composição química da célula e permite afirmar que, em caso de exposição às radiações, as moléculas atingidas em maior número serão moléculas de água ${ }^{18}$. Os efeitos da radiação em células, por sua vez, ocorrem em quatro etapas: efeitos físicos, químicos, biológicos e orgânicos (Figura 5). É possível separar essas quatro fases cronologicamente: as ionizações ocorrem cerca de $10^{-15}$ segundos após a exposição, enquanto a quebra de um íon radical ou de uma molécula excitada leva pelo menos $10^{-14}$ segundos. Isso leva à formação de produtos químicos, cuja estrutura e distribuição são tóxicas. A fase biológica é caracterizada por reações enzimáticas, que visam reparar e reduzir o dano da radiação. Supõe-se que demora alguns segundos antes do início das reações enzimáticas para reparar DNA danificado. Os efeitos biológicos são efeitos que podem ocorrer ou não, ao 
longo da vida do individuo e de sua linhagem, são eles os sintomas e doenças 19.

Figura 5 - Efeitos da radiação em células

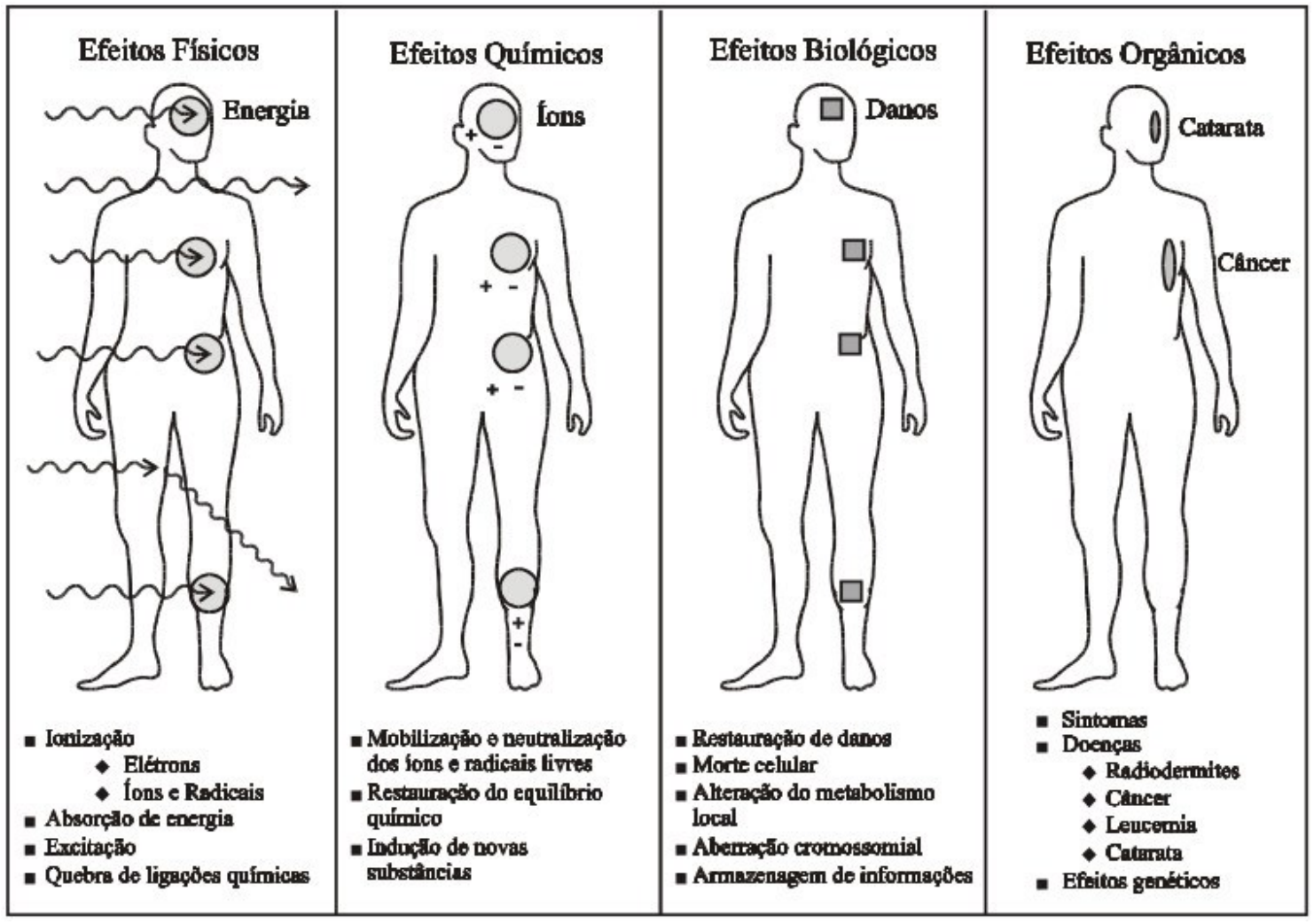

Fonte: RADIOPROTEÇÃO E DOSIMETRIA: FUNDAMENTOS 20 


\subsection{Espectroscopia no Infravermelho}

A espectroscopia no infravermelho (IV) é utilizada para obter informações sobre a natureza das ligações de uma molécula e de obter informações sobre a geometria molecular, a partir de suas transições vibracionais ou rotacionais ${ }^{21}$. Quase todos os compostos que possuam ligações covalentes absorvem várias frequências na região do IV, sejam de natureza orgânica ou inorgânica. Região essa que envolve comprimentos de onda maiores do que os associados à luz visível e menores do que os associados a micro-ondas. O interesse da química é na região vibracional do infravermelho ${ }^{19}$. O infravermelho vibracional, em termos de número de onda vai de $4000 \mathrm{~cm}^{-1}$ a $400 \mathrm{~cm}^{-1}$ ou em comprimento de onda que vai de $2,5 \mu \mathrm{m}$ a $15 \mu \mathrm{m}$,(Tabela 1 ) em um modo geral utiliza-se o número de onda como unidade pois essa é diretamente proporcional à energia 22.

Tabela 1 - Regiões do infravermelho

\begin{tabular}{|c|c|c|c|}
\hline Região & $\begin{array}{l}\text { Intervalo de } \\
\text { Número de onda }(\overline{\mathrm{U}}) \\
\left.\mathrm{cm}^{-1}\right)\end{array}$ & $\begin{array}{l}\text { Região em } \\
\text { comprimento de } \\
\text { onda }(\lambda), \mathrm{nm}\end{array}$ & $\begin{array}{l}\text { Região de } \\
\text { Frequência (v), Hz }\end{array}$ \\
\hline$\overline{P r o ́ x i m o ~(N I R) ~}$ & 12.800 a 4.000 & 780 a 2.500 & $\begin{array}{l}3,8 \times 10^{14} \text { a } 1,2 \times \\
10^{14}\end{array}$ \\
\hline Médio (MID) & 4.000 a 200 & 2.500 a 5.000 & $\begin{array}{l}1,2 \times 10^{14} \text { a } 6,0 \times \\
10^{12}\end{array}$ \\
\hline Distante (FIR) & 200 a 10 & 5.000 a 100.000 & $\begin{array}{l}6,0 \times 10^{14} \text { a } 3,0 \times \\
10^{11}\end{array}$ \\
\hline
\end{tabular}

Fonte: Autor da dissertação

Somente ligações que possuam modos vibracionais com variação de momento de dipolo elétrico diferentes de 0 (Figura 6) são observadas na espectroscopia de infravermelho, pois a radiação interage com o campo elétrico alternado, produzido pela mudança de distribuição de cargas que acompanham a vibração. 
Figura 6 - Momento molecular resultante, de moléculas de $\mathrm{CO}_{2}$ e $\mathrm{H}_{2} \mathrm{O}$.
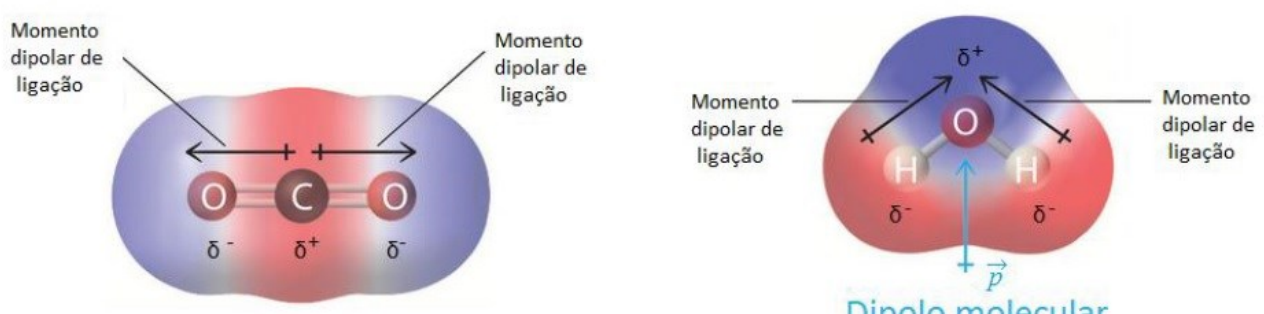

Dipolo molecular

Fonte - Adaptado de Principles of General Chemistry ${ }^{23}$

Os átomos em uma molécula nunca estão estáticos. Em uma molécula, o número de vibrações e a descrição dos modos vibracionais podem ser previstas a partir da simetria da molécula e da aplicação da teoria de grupo ${ }^{24}$. Os principais modos vibracionais ativos no infravermelho estão representados na Figura 7.

Figura 7 - Modos de vibrações moleculares.

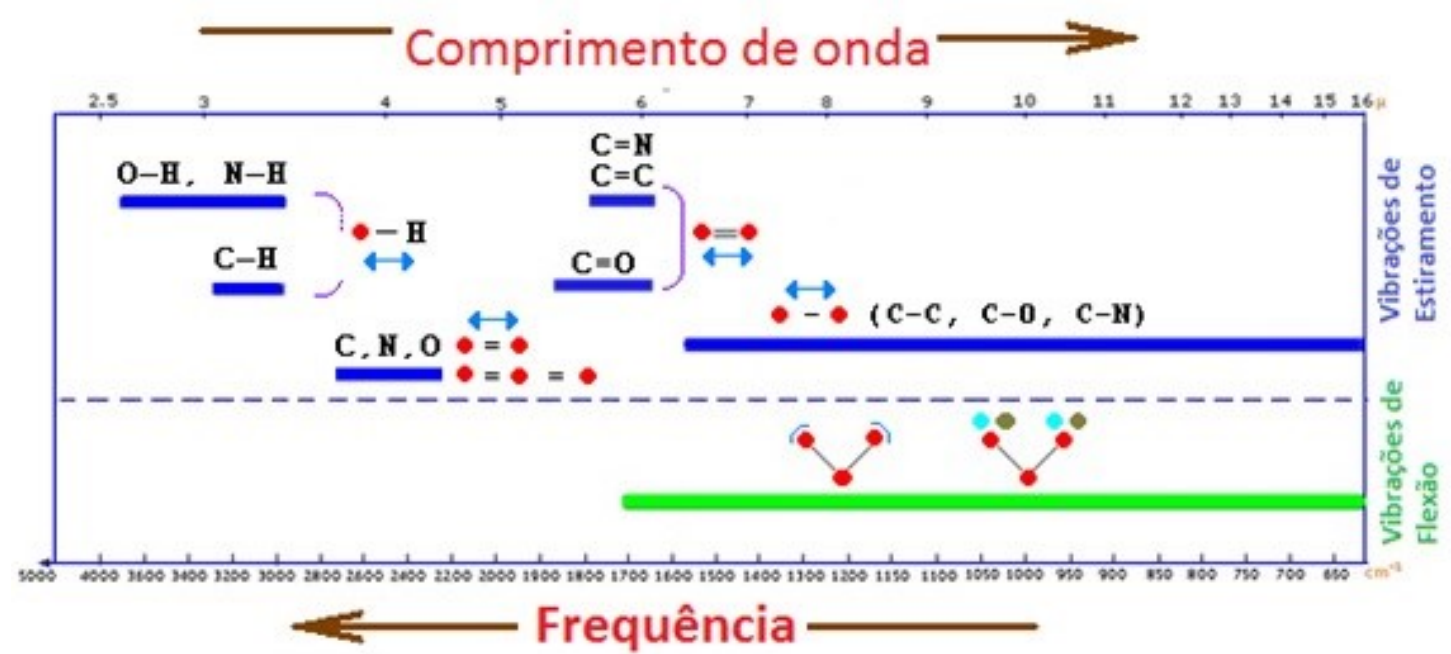

Fonte - Adaptado de Evaluation of Microscopic Analytical Techniques for the Analysis of Artists' Materials 25

Em uma visão geral, existem seis modos de vibração de interesse: estiramento simétrico, estiramento assimétrico, tesoura ou dobramento angular, balanço (wag), rotação e torção (twist). Exemplos desses modos de vibração para uma molécula linear e uma não linear estão ilustrados na Figura 8. 
Figura 8 - Modos de vibração para uma molécula linear e não linear

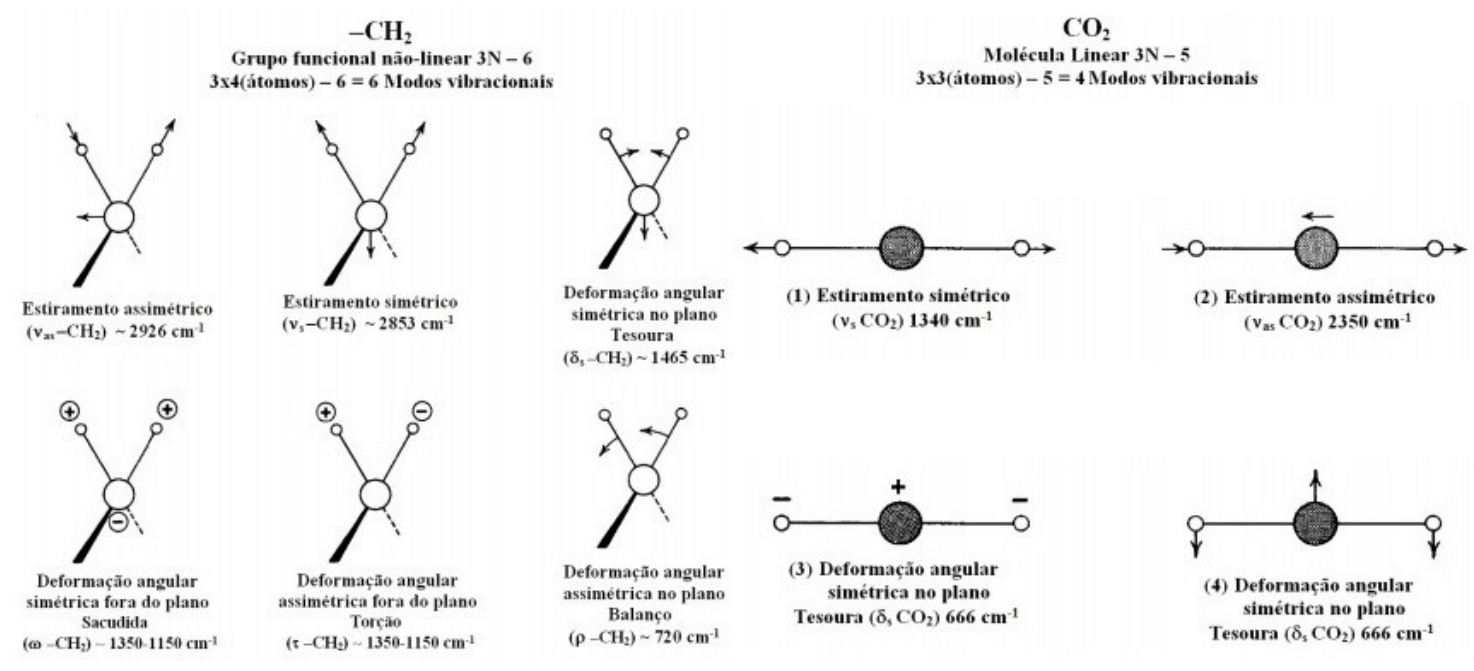

Fonte: Adaptado de Identificação Espectrométrica de Compostos Orgânicos ${ }^{26}$

O equipamento de espectroscopia utiliza um feixe infravermelho que interage com a amostra e detecta os seus grupos funcionais expressos em vibrações moleculares. Esses grupos indicam as características bioquímicas da amostra. Nesse trabalho utilizou-se o espectrômetro por transformada de Fourier acoplado a um acessório de reflexão atenuada. A radiação de uma fonte monocromática é divida igualmente em dois feixes pelo divisor de feixe ("beamsplitter"). Um feixe segue em direção ao espelho fixo no qual reflete de volta para o divisor de feixe para posteriormente seguir em direção ao detector. Paralelamente o outro feixe segue em direção ao espelho móvel o qual também reflete esse feixe, voltando para o divisor após interagir com o feixe vindo do espelho fixo. À medida que o espelho móvel percorre determinada distância a interação desses dois feixes com diferentes comprimentos de onda é registrada em um interferograma. Esse registro fornecido pelo detector contém informações sobre a quantidade de energia absorvida em cada comprimento de onda (frequência) ${ }^{22}$. A transformada de Fourier é uma ferramenta matemática que extrai as frequências individuais as quais foram absorvidas e gera o espectro, conforme ilustrado na Figura 9. 
Figura 9 - Diagrama esquemático de um Espectrômetro por Transformada de Fourier.

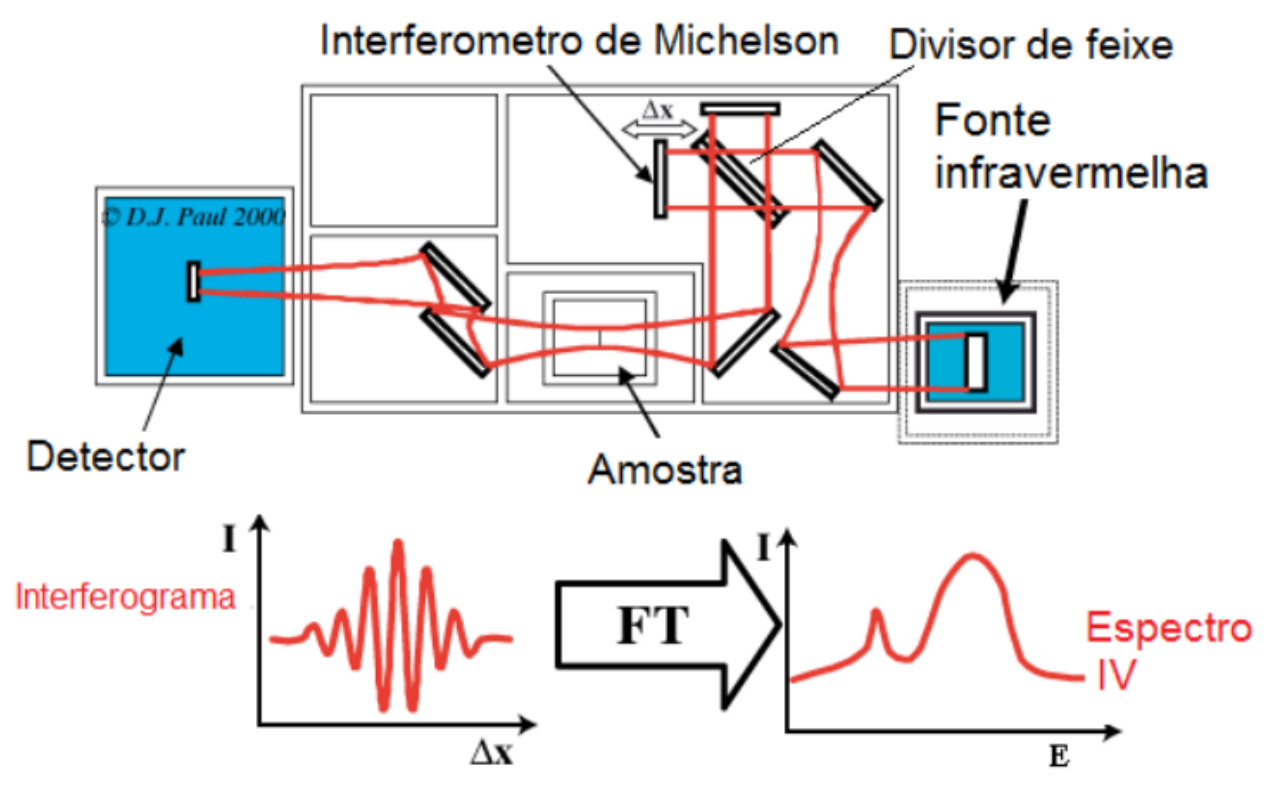

Fonte: Adaptado de: Time resolved FTIR study of spectral tuning and thermal dynamics of midIR QCLs. ${ }^{27}$

\subsubsection{Acessório de Reflexão Total Atenuada (ATR)}

O ATR opera medindo as mudanças que ocorrem em um feixe infravermelho (IR) refletido, quando em contato com uma amostra. Um feixe de IR é direcionado para um cristal opticamente denso com um alto índice de refração. Esta reflectância interna cria uma onda evanescente que se estende para além da superfície do cristal na amostra mantida em contato com o cristal, conforme representado na figura 10 . Em regiões do espectro Infravermelho onde a amostra absorve energia, a onda evanescente será atenuada. O feixe atenuado retorna ao cristal e é direcionado para o detector no espectrômetro. $O$ detector registra o feixe atenuado em um interferograma, que pode então ser usado para gerar um espectro aplicando-se a transformada de Fourier. 
Figura 10 - Representação de Funcionamento do ATR.

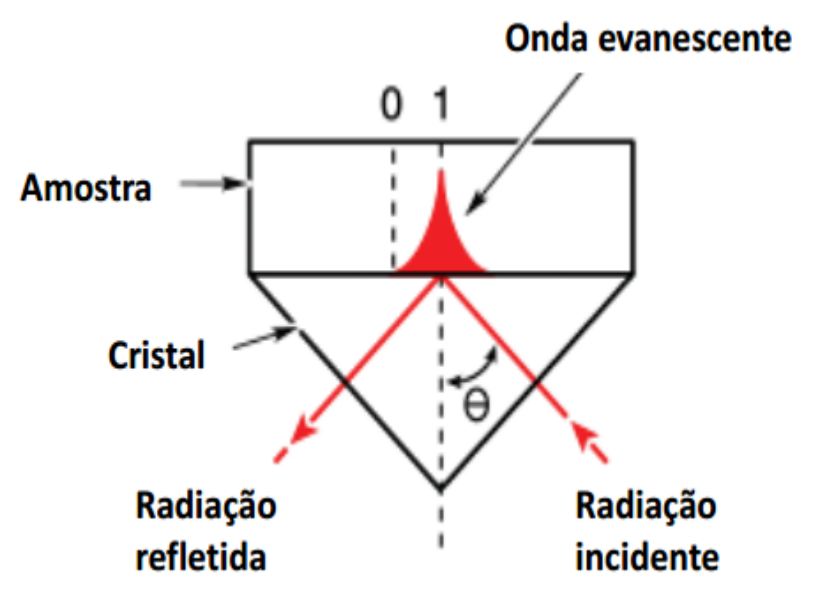

Fonte: Ablação De Pele Queimada Com Laser De Pulsos Ultra-Curtos Para Promoção Da Cicatrização. Avaliação Por Tomografia Por Coerencia Óptica, Histologia, Atr-Ftir E Microscopia Não Linear 28

\subsection{FTIR em Tecidos Mineralizados}

A espectroscopia no infravermelho FTIR é capaz de detectar alterações bioquímicas de materiais biológicos, permitindo a caracterização. Atualmente, as aplicações da técnica são vastas, além de ser utilizada na avaliação das propriedades químicas de matérias e processos biológicos, a técnica de espectroscopia FTIR também é empregada na melhoria do processo de fabricação de medicamentos e alimentos. Nos últimos anos, as aplicações de técnicas espectroscópicas em estudos biológicos aumentaram bastante, e particularmente pesquisas clínicas relacionadas à detecção e possível diagnóstico não invasivo de câncer por meios espectroscópicos têm atraído a atenção tanto de pesquisadores clínicos como não clínicos. Como foi descrito anteriormente na introdução deste trabalho, as características minerais, como o tamanho e a perfeição do cristalito (cristalinidade), teor de fosfato, teor de carbonato e ambiente mineral podem ser substancialmente alterados em função do tipo de tecido, idade e patologia. Desta maneira, a intenção final de utilização futura de técnicas moleculares seria um diagnóstico clínico não invasivo precoce ao diagnóstico de nível celular. Tradicionalmente, para finalidades de pesquisa e estudo do tecido ósseo, são utilizadas as técnicas de difração de raios $X$, ressonância magnética nuclear, ressonância de spin eletrônico e espectroscopia 
de infravermelho de transformação de Fourier (FTIR) permitindo a identificação da natureza das fases minerais presentes. A técnica de FTIR permite a análise química dos componentes orgânicos e minerais do osso de modo que regiões específicas do tecido podem ser analisadas, conforme ilustra a figura 11, enquanto que a tabela 2 demonstra as bandas de absorção relativas no tecido ósseo 29,30 .

Figura 11 - Espectro de absorção na região do infravermelho do tecido ósseo.

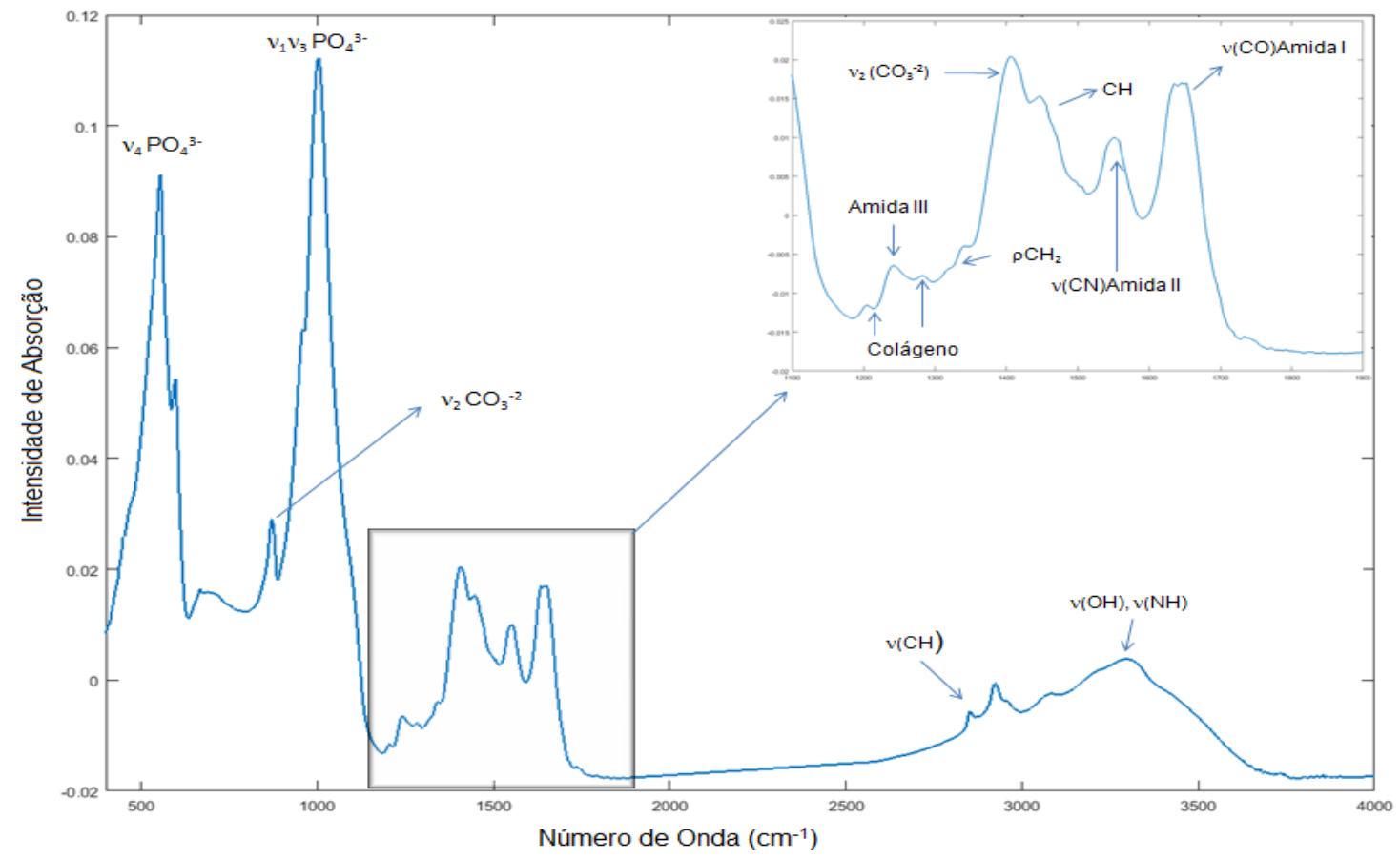

Fonte: Autor da dissertação 
Tabela 2 - Bandas de absorção relativas ao tecido ósseo ${ }^{31}$

\begin{tabular}{|c|c|}
\hline Número de onda $\left(\mathrm{cm}^{-1}\right)$ & Atribuição \\
\hline 472 & $\mathrm{v}_{2} \mathrm{PO}_{4}^{3-}$ \\
\hline $560-617$ & $v_{4} \mathrm{PO}_{4}^{3-}$ \\
\hline $860-890$ & $\mathrm{v}_{2} \mathrm{CO}_{3}{ }^{-2}$ \\
\hline $957-962$ & $v_{1} \mathrm{PO}_{4}^{3-}$ \\
\hline 1003-1005 & $\mathrm{v}_{3} \mathrm{HPO}_{4}{ }^{2-}$ \\
\hline 1006-1055 & $v_{3} \mathrm{PO}_{4}^{3-}$ \\
\hline 1123,1143 & $v_{3} \mathrm{H} \mathrm{PO}_{4}^{2-}$ \\
\hline $1200-1340$ & Amida III + Estrutura do Colágeno \\
\hline $1145-1409$ & $\mathrm{CO}_{3}^{2-}$ \\
\hline $1147-1452$ & $\mathrm{CH}_{2}$ \\
\hline $1480-1553$ & Amida II $+v_{3} \mathrm{CO}_{3}^{2-}+\mathrm{N}-\mathrm{H}+\mathrm{C}-\mathrm{N}$ \\
\hline $1634-1625$ & Amida I: Folhas Beta \\
\hline $1595-1720$ & Amida I Alfa Hélice \\
\hline 1642 & Amida I $+\mathrm{H}_{2} \mathrm{O}$ \\
\hline 3072 & Amida I - Crosslinks de colágeno \\
\hline 1690 & Amida I - Crosslinks de colágeno DHLNL \\
\hline 2950-2853 & $\mathrm{C}-\mathrm{H}$ \\
\hline 3083 & Amida B \\
\hline $3550-2900$ & $\mathrm{H}_{2} \mathrm{O}$ \\
\hline 3570 & $\mathrm{OH}^{-}$ \\
\hline
\end{tabular}

Fonte: Adaptado de Avaliação In Vitro dos efeitos da radiação ionizante em tecido ósseo Bovino por Epectroscopia ATR-FTIR e Análise Dinâmico- Mecânica, 2013.

\subsection{Tecido Ósseo}

O osso é um tecido conjuntivo mineralizado que apresenta quatro tipos de células: osteoblastos, células de revestimento do osso, osteócitos e osteoclastos. O osso exerce funções importantes no corpo como, locomoção, suporte e proteção para tecidos moles e órgãos vitais, armazenamento de cálcio e fosfato e alojamento de medula óssea. O osso é composto por sais inorgânicos e matriz orgânica. A matriz orgânica contém $90 \%$ de proteínas de colágeno, predominantemente de colágeno tipo I e proteínas não colágenas, incluindo osteocalcina, osteonectina, osteopontina, fibronectina e osso sialoproteína II, proteínas ósseas morfogenéticas (BMPs) e fatores de crescimento ${ }^{32}$.

A parte orgânica da matriz óssea é formada 85 a $90 \%$ por fibras colágenas, constituídas principalmente por colágeno tipo I que se organiza em 
estruturas fibrilares que tem origem na microfibrila, conforme ilustra a figura 12. A formação das microfibrilas se dá a partir das interações das moléculas de tropocolágeno. Além de pequenas quantidades de outras proteínas, as ligações cruzadas de colágeno são responsáveis pela resistência à tração e elasticidade do tecido ${ }^{33}$.

Figura 12 - Fibra de Colágeno tipo I e sua organização em diversas escalas.

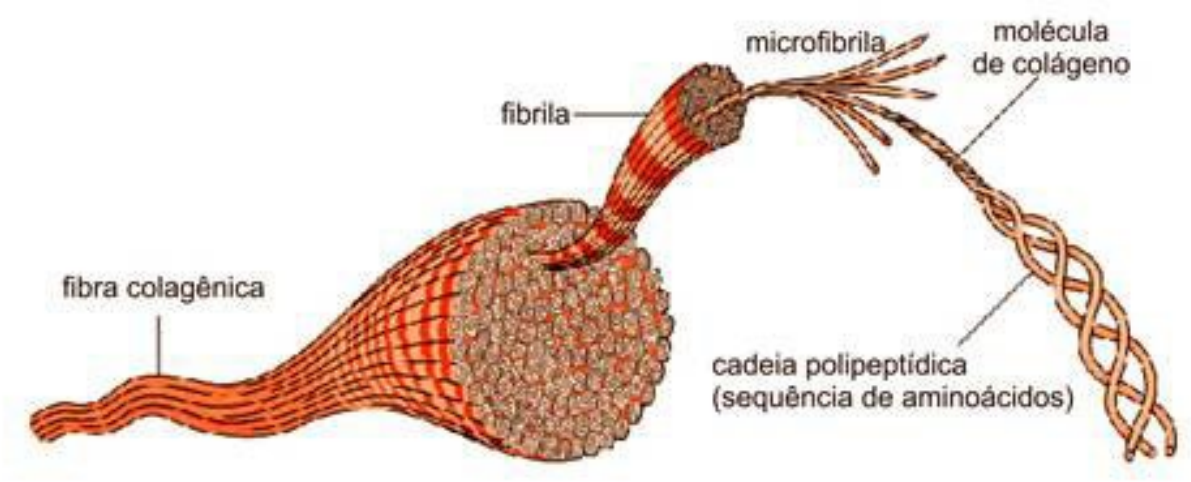

Fonte: Spectroscopic Characterization of Collagen Cross-Links in Bone ${ }^{34}$

A extensão e o tipo da ligação cruzada estão diretamente ligados com a idade e função do tecido. $\mathrm{O}$ aumento da tensão nas fibras de colágeno aumenta o número de ligações cruzadas para produzir as propriedades mecânicas ideais para dada função do organismo. Ligações estas que fornecem as propriedades viscoelásticas no tecido ósseo ${ }^{35}$. A parte mineral dos tecidos duros, tanto nos ossos como nos dentes, é composta pela forma cristalina do fosfato de cálcio similar à hidroxiapatita $\mathrm{Ca}_{10}\left(\mathrm{PO}_{4}\right)_{6}(\mathrm{OH})_{2}$. A família mineral das apatitas $A_{10}\left(B_{4}\right)_{6} X_{2}$ é cristalizada em prismas hexagonais, onde $A$ é usualmente $\mathrm{CA}_{2}{ }^{+}$ ou $\mathrm{Pb}_{2}{ }^{+}, \mathrm{B}$ é $\mathrm{P}_{5}{ }^{+}$ou $\mathrm{As}_{5}{ }^{+}$e $X$ é $\mathrm{F}^{-}, \mathrm{Cl}^{-}$ou $(\mathrm{OH})^{-}$. Este material possui estrutura frágil e sua resistência mecânica é pobre, mas sua associação com fibras colágenas confere ao tecido ósseo alto grau de rigidez e resistência à tensão mecânica ${ }^{31}$ 36,37. Também são encontradas quantidades significativas de bicarbonato, sódio, potássio, citrato, magnésio, carbonato, fluoreto, zinco, bário e estrôncio ${ }^{32}$. A figura 13 ilustra o fêmur humano que é constituído por duas partes principais: a diáfise formada por tecido ósseo compacto e as epífises 
constituídas por tecido ósseo esponjoso. O fêmur humano é morfologicamente e histologicamente muito semelhante ao osso bovino, podendo este ser usado em substituição ao primeiro com considerável facilidade na obtenção, desde que observadas as devidas considerações éticas do modelo experimental.

Figura 13 - llustração esquemática da estrutura óssea do fêmur.

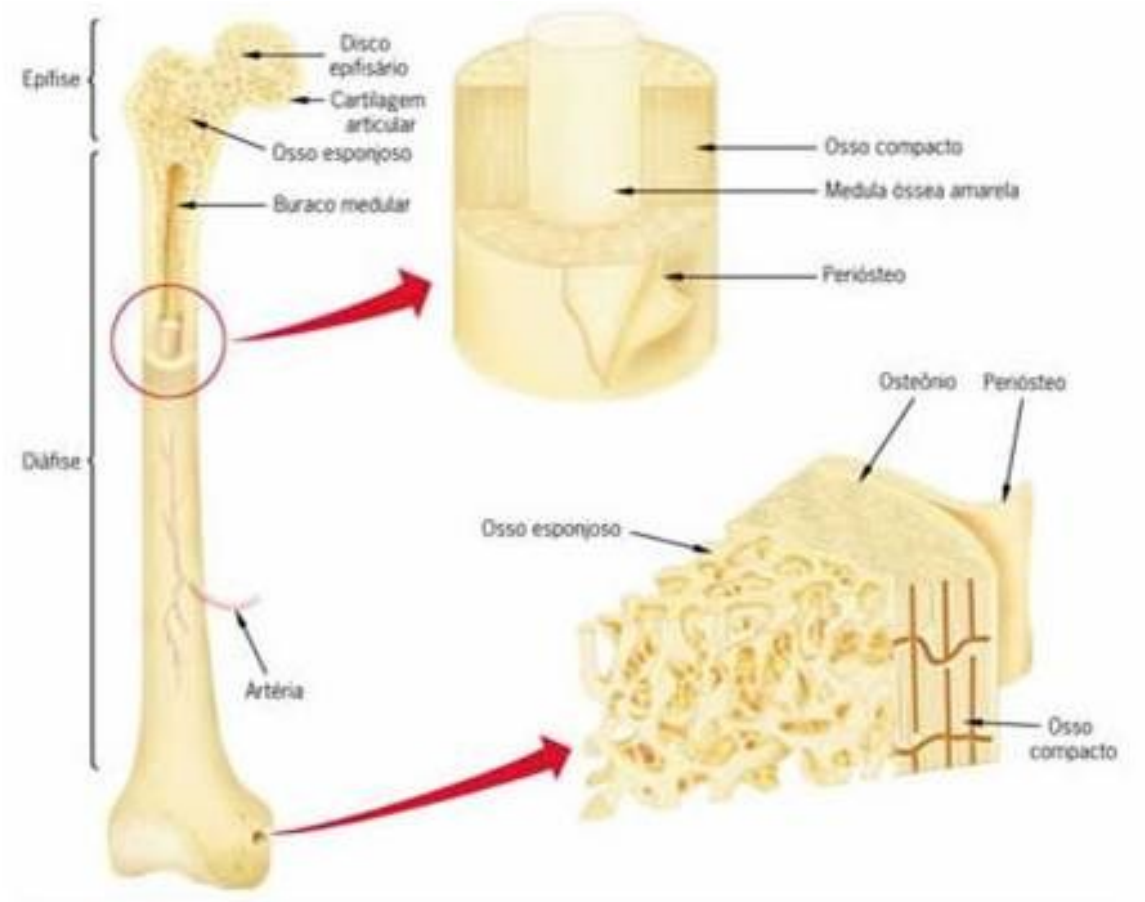

Fonte: Placas ósseas confeccionadas a partir de diáfise cortical equina na osteossíntese femoral em coelhos 38 


\section{MATERIAL E MÉTODOS}

Este estudo foi aprovado pelo CEUA IPEN 120/13 (Anexo 1). Sendo que 100 amostras foram irradiadas com radiação ionizante $\left(\mathrm{Co}^{60}\right)$ e 10 foram utilizadas como controle negativo, não irradiadas. As amostras foram submetidas às mesmas condições de processamento, embalagem e estocagem.

\subsection{Processamento dos Ossos}

Os fêmures bovinos utilizados foram adquiridos em frigorífico certificado para o processamento dos ossos, de acordo com os requerimentos específicos para o armazenamento a $-20^{\circ} \mathrm{C}$. Foram selecionados 5 fêmures bovinos provenientes de animais diferentes, garantindo assim a variabilidade das amostras. Foram utilizados 2 fragmentos de cada fêmur por grupo. Os ossos bovinos foram limpos para reduzir sua contaminação inicial. Após a limpeza inicial, foram retirados os tecidos moles associadas ao osso: o periósteo na parte externa e a medula óssea na parte interna. Posteriormente, foram embalados em filme plástico de uso doméstico e estocados em freezer à $-20^{\circ} \mathrm{C}$. Foram utilizadas as diáfises dos ossos e as epífises foram seccionadas e descartadas, conforme ilustra a figura 14. Os cortes da região da diáfise para a obtenção das amostras com dimensão de $10 \mathrm{~mm}^{2}$ de área foram realizados com auxilio de uma cortadeira (Accutom-5, Struers s/a, Ballerup, Dinamarca). Foram preparadas 110 amostras de tecido ósseo bovino irradiado com diferentes doses de radiação gama. Os fragmentos de osso bovino para obtenção das amostras foram provenientes de diferentes animais para assegurar a necessária variabilidade da amostra. Finalmente, as amostras de osso foram lixadas até atingirem a espessura de $2 \mathrm{~mm}$ e foi feito um desgaste na região da amostra correspondente a região medular da diáfise. Este desgaste foi utilizado como uma referência desta região da amostra para posterior identificação no momento da análise, conforme ilustra a figura 15. 
Figura 14 - Estrutura óssea e locais de corte.
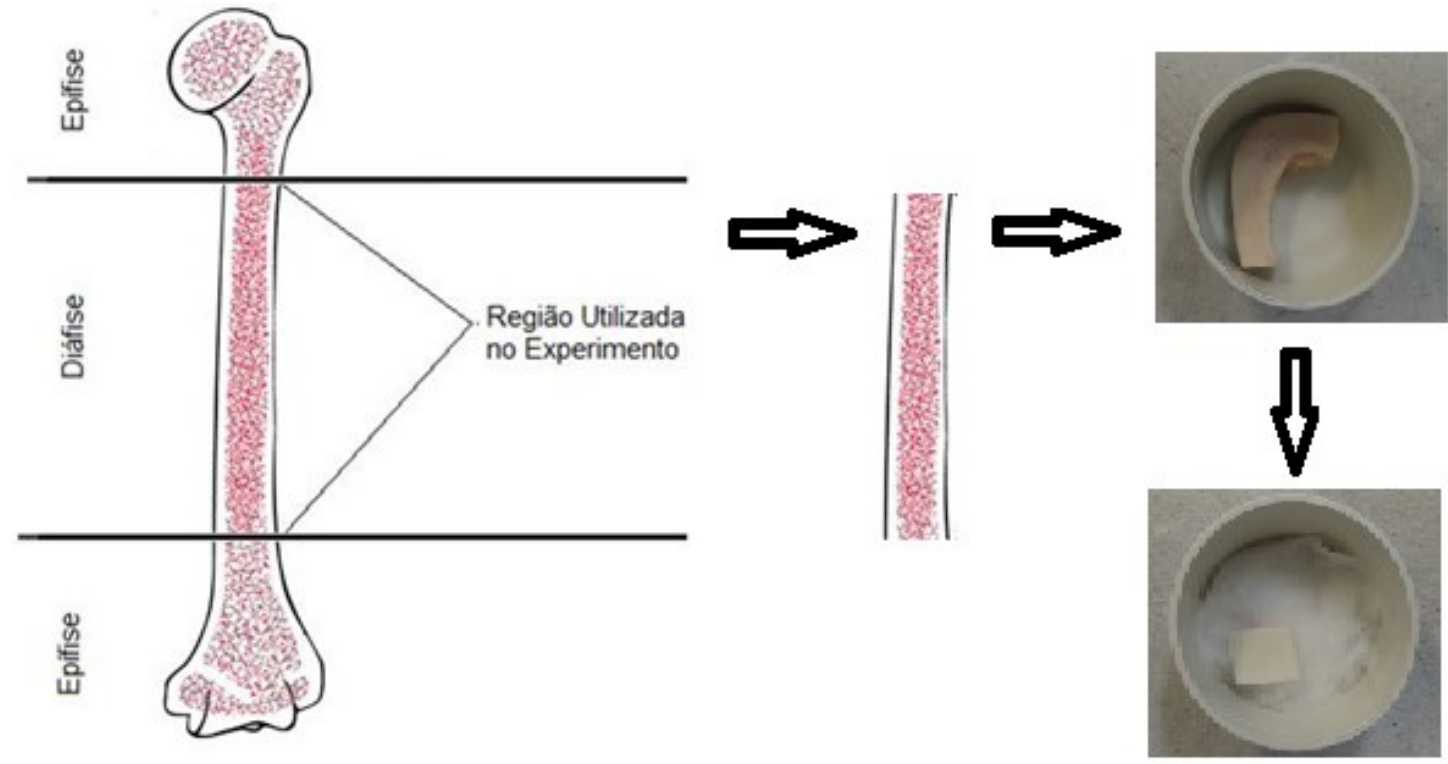

Fonte: Adaptado de Perspectives on Pathophysiology. ${ }^{39}$

Figura 15 - Imagem de uma das amostras utilizadas no experimento. A seta indica a região da amostra mais próxima à medula da diáfise de onde ela foi obtida. Notar o desgaste realizado na região para ser utilizado como referência durante as análises.

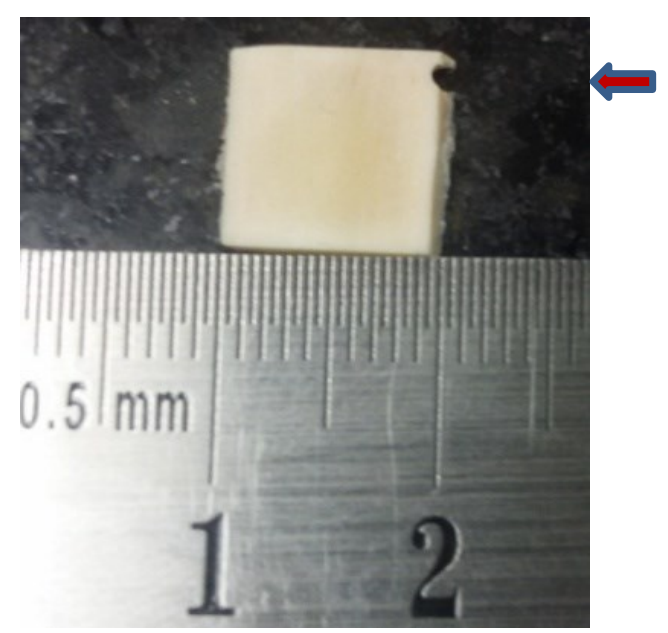

Fonte: Autor da dissertação 


\subsection{Irradiação}

A irradiação das amostras com radiação- $\gamma$ foi feita no Centro de Tecnologia das Radiações (CTR) do IPEN-CNEN/SP em fonte de Cobalto-60 tipo Gammacell com taxa de dose de 0,79 kGy/h, conforme ilustrado na figura 16. As 110 amostras foram distribuídas de maneira uniforme entre os onze grupos ( $n=10$ ), ou seja, cada grupo continha duas amostras de cada um dos cinco ossos, e embaladas individualmente em tubos eppendorf com algodão umedecido com água destilada para serem submetidas às irradiações independentes. As amostras do grupo controle negativo foram submetidas à refrigeração até a análise por FTIR. Os grupos irradiados foram tratados com doses independentes de radiação gama, conforme ilustra a tabela 3.

Figura 16 -- Irradiador tipo Gammacell localizado no Centro de Tecnologia das Radiações (CTR) do IPEN-CNEN/SP.

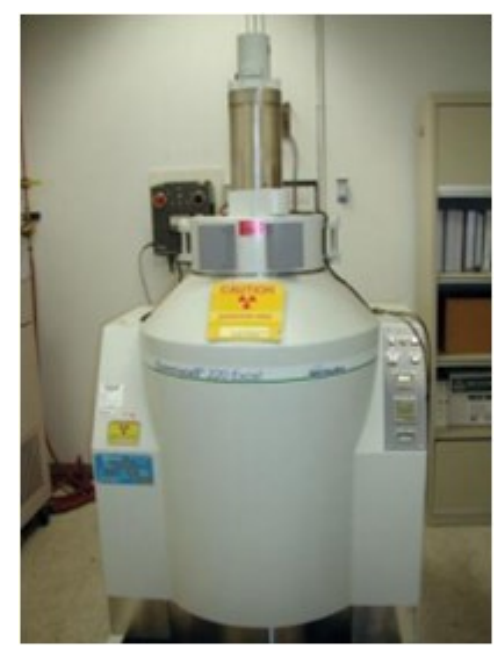

Fonte: Autor da dissertação 
Tabela 3 - Doses Administradas

\begin{tabular}{cc}
\multicolumn{3}{c}{ Dose por Grupo (kGy) } \\
\cline { 2 - 3 } Grupo 1 (G1) & Controle \\
Grupo 2 (G2) & 0.002 \\
Grupo 3(G3) & 0.004 \\
Grupo 4 (G4) & 0.07 \\
Grupo 5 (G5) & 1.0 \\
Grupo 6 (G6) & 10 \\
Grupo 7 (G7) & 15 \\
Grupo 8 (G8) & 25 \\
Grupo 9 (G9) & 35 \\
Grupo 10 (G1C & 50 \\
Grupo 11 (G11 & 60 \\
\hline
\end{tabular}

Fonte: Autor da dissertação

\subsection{Espectroscopia ATR-FTIR}

A escolha da técnica com uso da transformada de Fourier tem a vantagem de ser rápida, pois permite o registro do interferograma contendo toda a região espectral de interesse, é sensível tanto aos componentes minerais como orgânicos do osso, permitindo assim o estudo das interações minerais e orgânicas, bem como as propriedades de cada componente individualmente. Trata-se de uma técnica não invasiva ${ }^{22}$.

As análises foram realizadas no laboratório de Biofotônica do Centro de Laser e Aplicações do IPEN. Foi utilizado um acessório de Reflexão Total Atenuada - ATR (SmartOrbit, Thermo Inc., EUA) acoplado a um espectrômetro no infravermelho por transformada de Fourier - FTIR (Nicolet 6700, Thermo Inc., EUA), conforme ilustra a figura 17. Cada amostra foi analisada em triplicata e em três regiões diferentes. A primeira região analisada foi a mais próxima à parte interna (medular) da diáfise, de acordo com desgaste referência previamente realizado. Em seguida foi analisada a região mais distante do desgaste referência que corresponde a parte externa da diáfise, portanto a que seria mais próxima à inserção do periósteo. Por fim, foi analisada a região intermediária entre estes dois pontos. Desta forma, foram obtidos nove espectros por amostra. O software utilizado na aquisição dos espectros foi o software OMNIC (Thermo 
Scientific ${ }^{\circ}$, Madison, WI, EUA). Os espectros foram salvos em formato CSV e analisados no programa Matlab 2015a (MathWorks R, Natick, MA, EUA). Os parâmetros utilizados na coleta dos espectros de FTIR estão expressos na Tabela 4.

Figura 17 - (A) espectrômetro no infravermelho por transformada de Fourier - FTIR (Nicolet 6700,Thermo Inc., EUA) , (B) acessório de Reflexão Total Atenuada - ATR (SmartOrbit, Thermo Inc., EUA)

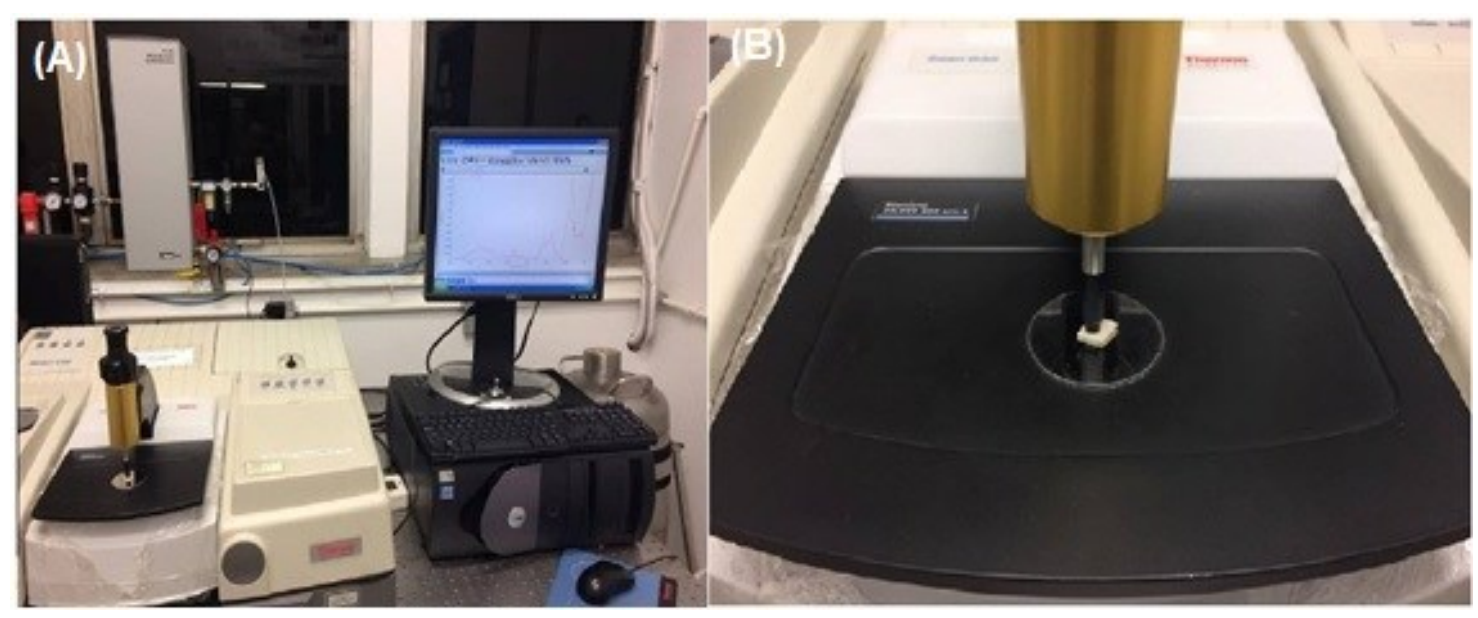

Fonte: Autor da dissertação

Tabela 4 - Parâmetros utilizados na aquisição dos espectros de FTIR

\begin{tabular}{lc}
\hline \multicolumn{1}{c}{ Parâmetros } & Valores \\
\hline Intervalos de Aquisição $\left(\mathbf{c m}^{-1}\right)$ & $4000-400$ \\
Resolução $\left(\mathbf{c m}^{-1}\right)$ & 4 \\
Velocidade de Aquisição $\left(\mathbf{c m}^{-1}\right)$ & 0,6329 \\
Varredura & 100 \\
Varredura Background & 100 \\
\hline
\end{tabular}

Fonte: Autor da dissertação 


\subsection{Forma de análise de resultados}

Para verificar se havia diferenças bioquímicas entre amostras irradiadas pelas diferentes doses, foi realizada análise multivariada utilizando a técnica de análise de componentes principais (PCA/LDA).

A área integrada sob uma banda de absorção no infravermelho é diretamente proporcional à quantidade de espécies que gera a banda. ${ }^{40}$ Para verificar quais componentes foram afetados pela irradiação, foram realizadas análises de área sob a curva das bandas relacionadas ao fosfato, às amidas I, II e III, ao carbonato e ao colágeno. Para a banda do fosfato (v1,v3 $\left.\mathrm{PO}_{4}{ }^{3-}\right)$ foi considerada a região de 900 a $1200 \mathrm{~cm}^{-1}$, para a amida I foi considerada a região de 1600 a $1720 \mathrm{~cm}^{-1}$, para amida II foi considerada a região de 1480 a $1600 \mathrm{~cm}^{-}$ 1, para a amida III foi considerada a região de 1200 a $1350 \mathrm{~cm}^{-1}$, para o carbonato foi considerada a região de 1200 a $1550 \mathrm{~cm}^{-1}$ e para o colágeno foi considerada a região de 1140 a $1240 \mathrm{~cm}^{-1}$. Para a análise de cristalinidade pela análise do índice cristalino, foi realizada a razão das bandas de material orgânico (Amida I + Amida II) pelo material inorgânico Fosfato $\left({ }_{v 1, v 3} \mathrm{PO}_{4}{ }^{3-}\right)$. Os dados obtidos foram analisados em ambiente Matlab, Prisma e Minitab.

Testes estatísticos foram estabelecidos de acordo com a normalidade dos dados encontrados nos cálculos de componentes moleculares e suas razões, para verificar a diferença estatística dos mesmos.

\subsubsection{Pré-processamento dos dados}

Para permitir comparações entre espectros, foi necessário o préprocessamento dos espectros, por possíveis variações durante a aquisição dos espectros, como, sutis diferenças na pressão do ATR, variações de temperatura no dia da realização das medidas, fatores esses que podem apresentar variações significativas nos espectros obtidos em diferentes regiões da mesma amostra. 


\subsubsection{Normalização vetorial}

Foi utilizada a normalização vetorial, calculada de acordo com as equações abaixo:

$$
\begin{aligned}
& \alpha_{\text {média }}=\frac{\sum_{\mathrm{k}} \mathrm{a}(\mathrm{k})}{\mathrm{k}} \\
& \alpha^{\prime}(\mathrm{k})=\mathrm{a}(\mathrm{k})-\alpha_{\text {média }} \\
& \alpha^{\prime \prime}(\mathrm{k})=\frac{\alpha^{\prime}(\mathrm{k})}{\sqrt{\Sigma_{\mathrm{k}}\left(\alpha^{\prime}(\mathrm{k})\right)^{2}}} \\
& \left.\sum_{\mathrm{k}} \alpha^{\prime \prime}(\mathrm{k})\right)^{2}=1
\end{aligned}
$$

onde amédia é a intensidade média dos pontos do espectro. O parâmetro $a(k)$ é a intensidade do espectro no ponto $k, \alpha^{\prime}(k)$ é o espectro subtraído pela sua média, e $\alpha^{\prime \prime}(k)$ é o espectro normalizado.

\subsubsection{Filtro de Savitzky-Golay}

Para melhores resultados com mínimo de ruído, adotou-se filtro de suavização de Savitzky-Golay com janelas de 11 pontos.

O filtro de suavização Savitzky-Golay consiste em subdividir o espaço amostral em subintervalos ímpares, e com método dos mínimos quadrados se obtêm uma função polinomial, onde um ponto central de intervalo é utilizado de referência para substituição do valor fornecido pela função.

\subsubsection{Análise de componentes principais (PCA)}

A análise PCA pode fornecer a variância mais significativa entre os grupos de espectros. Esta técnica reduz a dimensionalidade da matriz de medição com o objetivo de representar os dados usando menor número de fatores ou componentes principais (PCs). O conjunto amostral é centrado na média, na sequência é obtida sua matriz de covariância. A partir dessa matriz 
extraem-se os auto valores e os auto vetores para que na sequência sejam organizados em ordem decrescente de valor de variância acumulada. A partir disso, essas variâncias podem ser projetadas e comparadas a cada grupo. As informações relevantes são separadas e torna-se mais evidente a inspeção visual. ${ }^{41}$

\subsubsection{Análise discriminante Linear (LDA)}

Esta A técnica LDA é uma generalização do algoritmo de discriminação linear de Fisher. Esse método é usado para modelar o conjunto amostral em duas classes ou mais. Neste trabalho o LDA foi usado para comparar o grupo controle com as variações de dose. Para este fim a construção do modelo, em cada comparação, o grupo controle foi referenciado com valor um e cada dose com valor zero. O conjunto de treinamento, no caso controle, compostas por 90 dados e o conjunto de validação foram compostas por 90 dados. ${ }^{42}$

Ao supervisionar duas classes, o algoritmo de classificação irá maximizar a variância entre as classes e minimizar a variância dentro das classes por meio de combinações lineares da matriz de dados assumindo uma relação linear entre as classes de amostra.

A análise discriminante linear (LDA) tem sido aplicada em diversas linhas de pesquisas no intuito de classificar produtos variados como: queijo ralado, óleo vegetal extra virgem, óleo de canola, girassol e soja, de acordo com as propriedades físicas e químicas, processos de obtenção e propriedades espectroscópicas. $43,44,45$.

\subsubsection{Cálculo de Área sobre as bandas de interesse}

Foi traçado o baseline das bandas de interesse citadas (fosfato; amidas I, II e III; carbonato e colágeno) de acordo com o descrito na tabela 2. Sendo que foi utilizada a segunda derivada dos espectros para localizar os pontos de mínimo da banda de interesse. Após essa etapa, foi obtida a área sob as bandas de interesse, calculando-se a integral da banda, conforme representado na figura 18. 
Figura 18 - Representação do cálculo de área da banda de Fosfato (900 a $\left.1200 \mathrm{~cm}^{-1}\right)$.

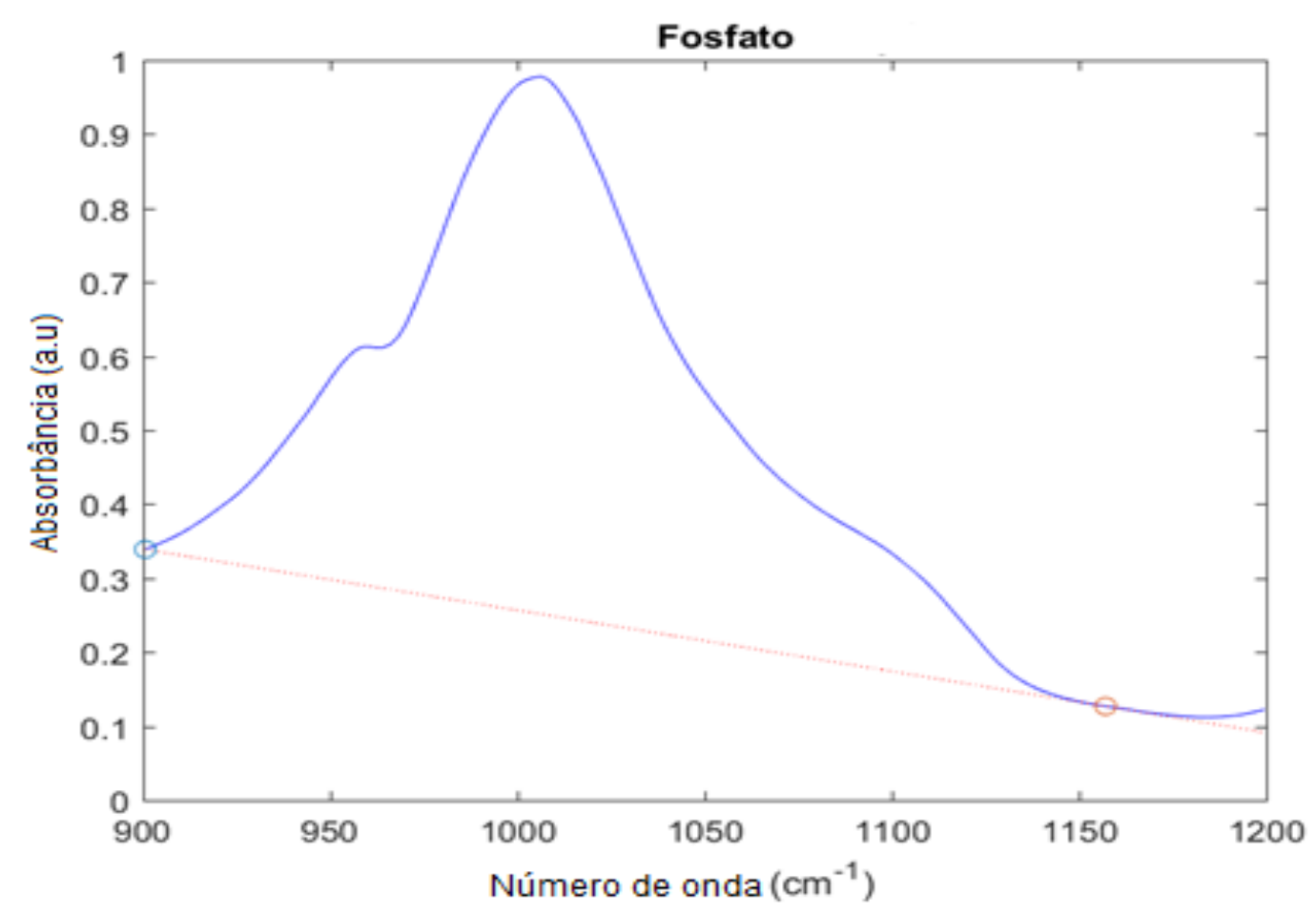

Fonte: Autor da dissertação

\subsubsection{Análise de Cristalinidade}

O pico localizado em $604 \mathrm{~cm}^{-1}$ é de particular interesse devido à sua boa resolução. Corresponde ao ambiente de fosfato apatitico e fornece informações diretas sobre o índice de cristalinidade da amostra. Quanto mais estreito o pico é, maior o índice de cristalinidade. Os números de onda de $\mathrm{A}=604 \mathrm{~cm}^{-1}$ e $\mathrm{B}=$ $564 \mathrm{~cm}^{-1}$ correspondem a bandas de fosfato $v_{4} \mathrm{PO}_{4} \mathrm{e}$ ambos aumentam quando a cristalinidade aumenta. A intensidade do número de onda de $C=590 \mathrm{~cm}^{-1}$ diminuirá, causando um aumento geral no valor do Índice de Cristalinidade. A Figura 19 ilustra as bandas mencionadas e sua intensidade ${ }^{46,47}$.

Para calcular o índice de cristalinidade a seguinte equação foi utilizada: 


$$
I C=\frac{A_{604}+B_{564}}{C_{590}}
$$

Figura 19 - Representação dos pontos utilizados para cálculo do Índice de Cristalinidade.

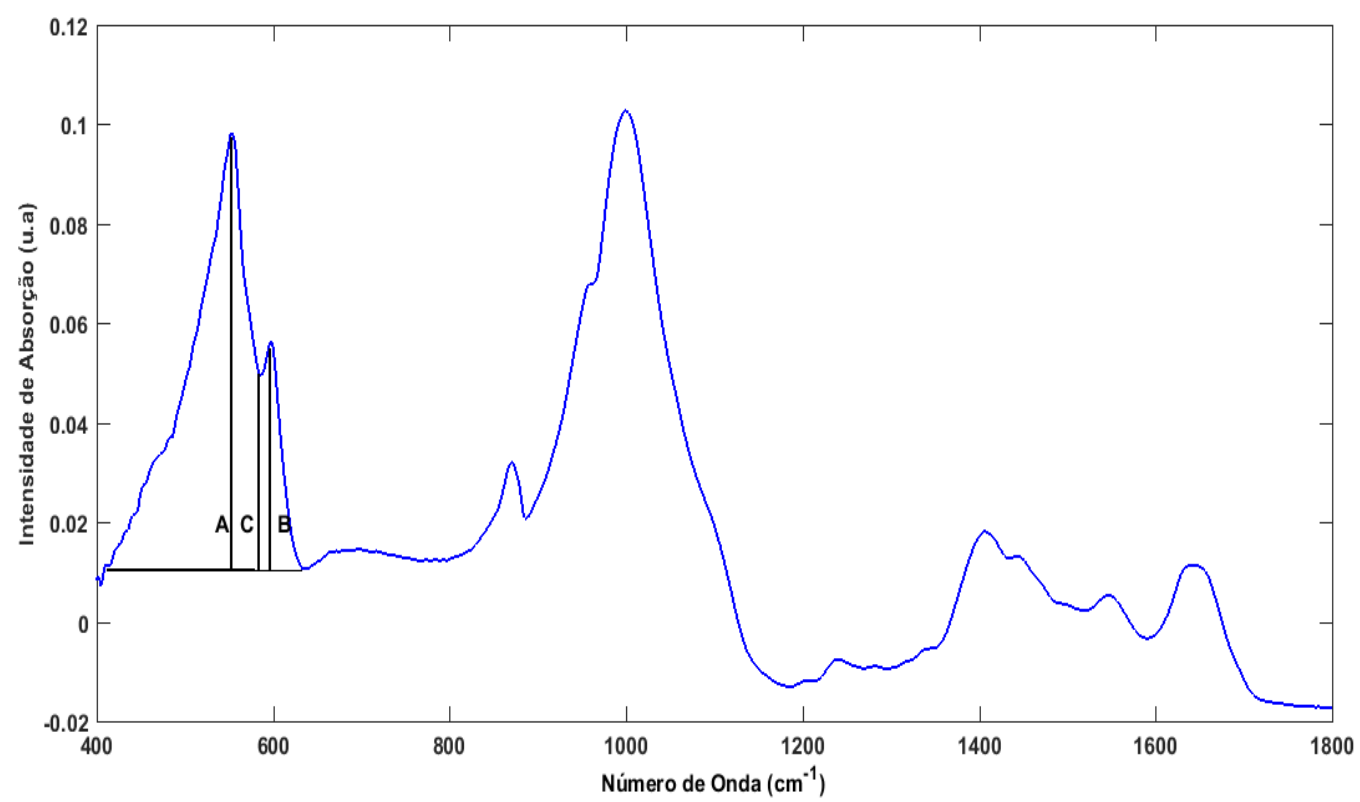

Fonte: Autor da dissertação

\subsubsection{Razão das áreas de Amida I + Amida II / Fosfato.}

Foi calculada a razão da área integrada de Amida I + Amida II (1480 a $\left.1800 \mathrm{~cm}^{-1}\right)$ pela área do Fosfato $v 1, v 3 \mathrm{PO}_{4}^{3-}\left(900 \mathrm{a}^{2} 1200 \mathrm{~cm}^{-1}\right)$. Esta razão representa a quantidade de mineral normalizado para a quantidade de colágeno presente ${ }^{40}$.

\subsubsection{Estatística}

As análises foram realizadas no software Matlab. A normalidade dos dados foi verificada e optou-se por utilizar o teste não paramétrico Kruskal-Wallis com nível de significância de 5\%. 


\section{RESULTADOS E DISCUSSÃO}

A escolha da técnica com uso da transformada de Fourier tem a vantagem de ser rápida, pois permite o registro do interferograma contendo toda a região espectral de interesse, é sensível tanto aos componentes minerais como orgânicos do osso, permitindo assim o estudo das interações minerais e orgânicas, bem como as propriedades de cada componente individualmente. Trata-se de uma técnica não invasiva. Noventa espectros de ATR-FTIR de cada grupo foram coletados, sendo que cada amostra foi medida 3 vezes em sua região externa (região em contato com músculos), 3 vezes na região média do osso e 3 vezes na região interna (região em contato com a medula óssea), para verificar se há diferenças entre a região externa, média e interna do tecido ósseo analisado, foi realizada a Analise de componentes principais, conforme Figura 20 .

Figura 20 = Analise de Componentes Pincipais (P.C.A) da região interna, média e externa das amostras em todos os grupos.
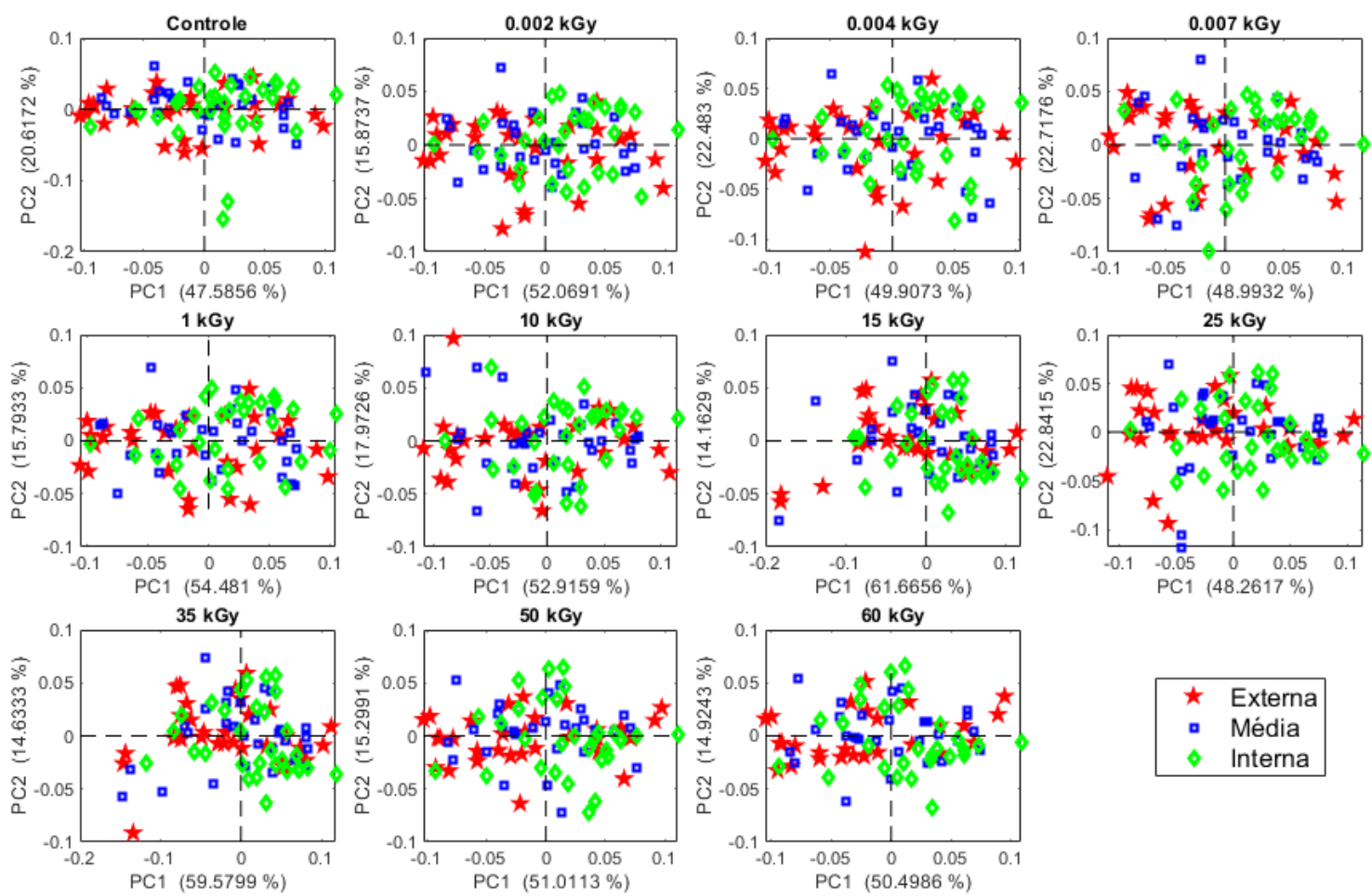

- Externa

Interna

Fonte: Autor da dissertação 
Foi realizado o pré-processamento dos dados e em seguida, realizou-se a Análise Discriminante Linear dos Componentes Principais - (PC-LDA), para avaliar as alterações em todo o espectro na região de interesse ( 400 a $1800 \mathrm{~cm}^{-}$ $\left.{ }^{1}\right)$. Primeiramente para avaliar se havia alguma diferença entre a parte interna, externa e meio do osso. Após essa análise em cada grupo (controle e irradiados), não foram encontradas diferenças. Em seguida a comparação foi realizada entre os grupos irradiados e o grupo controle.

A figura 21 mostra a média espectral de cada grupo, após normalização vetorial. Notar que não exibe um padrão com grandes diferenças aparentes entre cada grupo. Também foi verificado que não houve a formação de novos compostos e todas as bandas previamente apresentadas na tabela 2 foram identificadas.

Figura 21 -Espectros médios de FTIR para amostras de osso bovino, irradiadas por radiação gama, em diferentes doses.

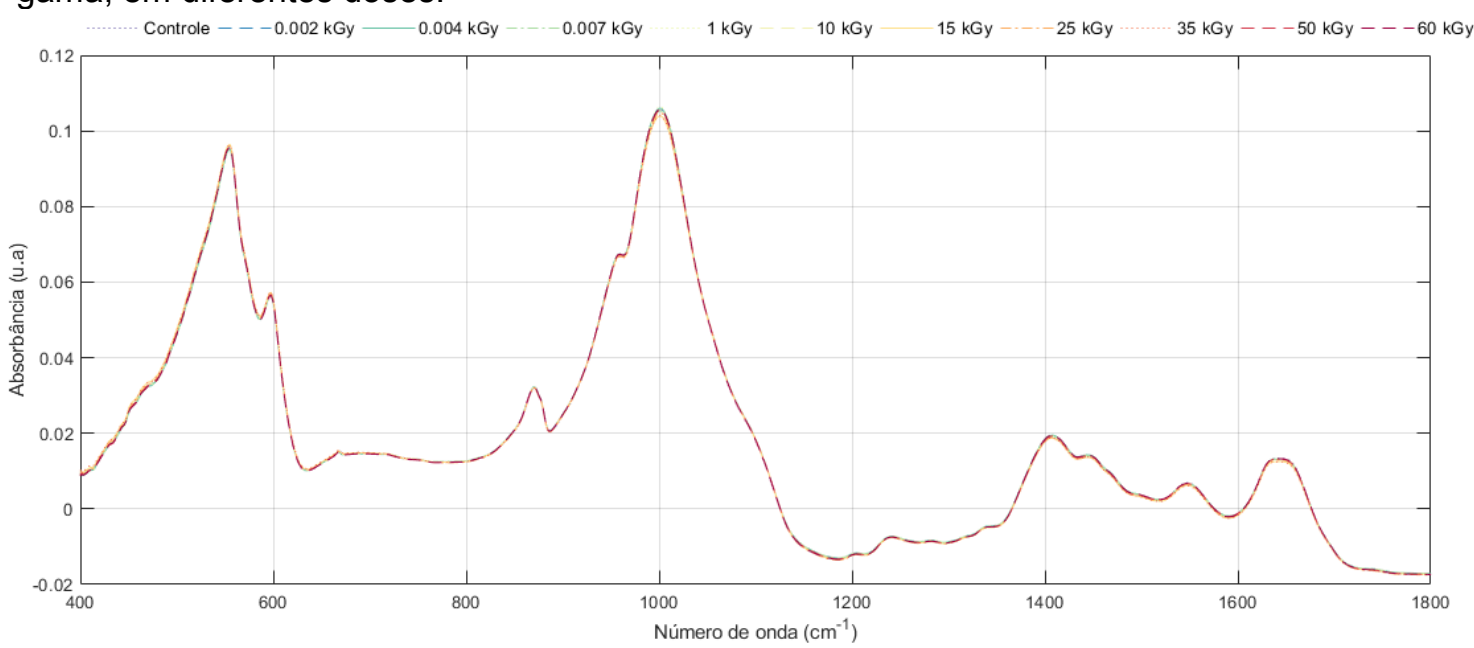

Fonte: Autor da dissertação 


\subsection{Análise de Componentes Principais (PCA/LDA)}

Houve diferença entre os grupos irradiados em relação ao grupo controle ao realizar análise multivariada pela técnica de PCA/LDA, conforme figuras 22 , 23 e 24 .

Figura 22 - PCA/LDA controle x 0.002kGy (A), PCA/LDA controle x 0.004kGy (B), PCA/LDA controle $\times 0.07 \mathrm{kGy}(\mathrm{C}), \mathrm{PCA} / \mathrm{LDA}$ controle $\times 1 \mathrm{kGy}(\mathrm{D})$
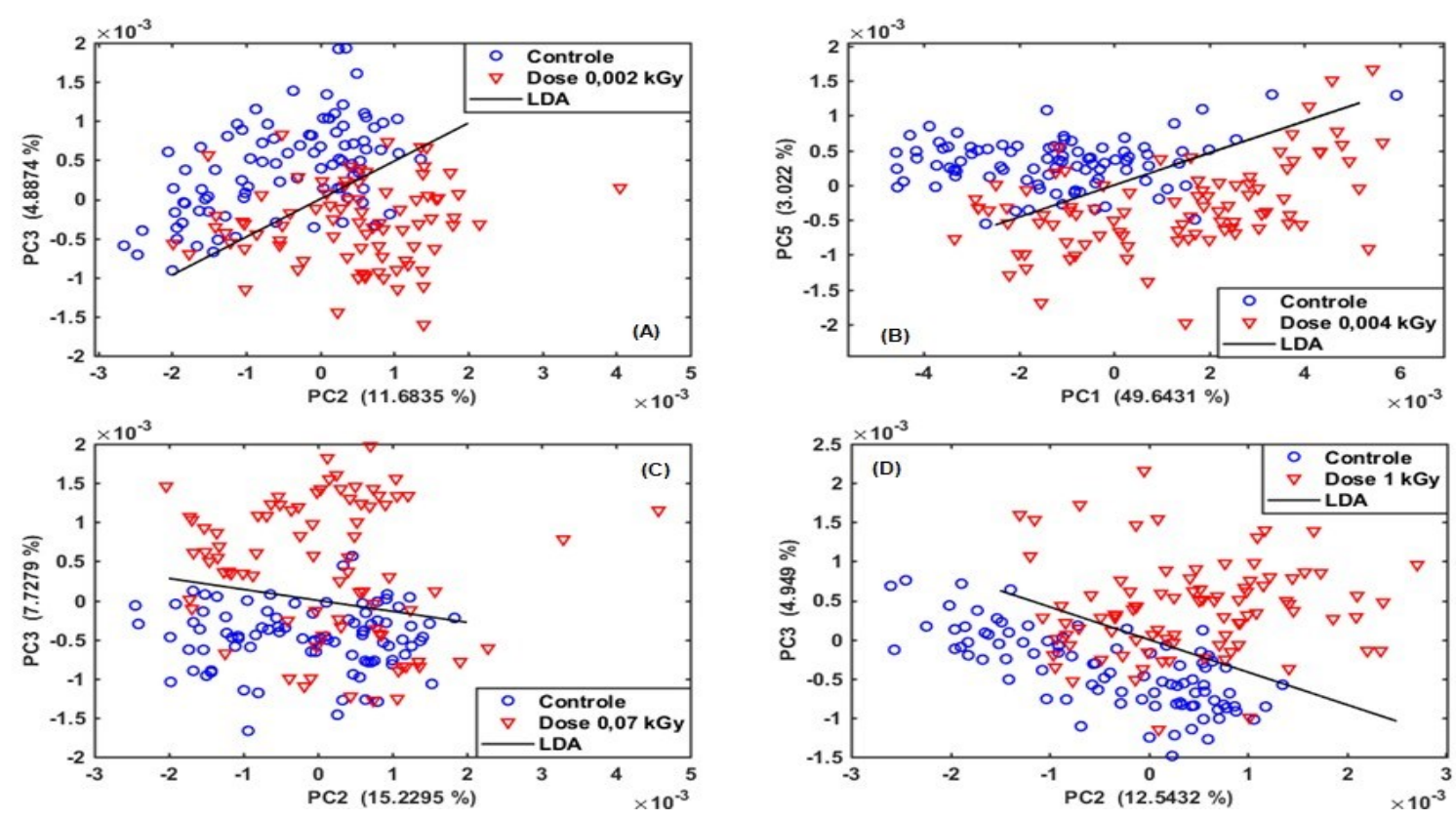

Fonte: Autor da dissertação

Na figura 22 os grupos de $0.002 \mathrm{kGy}, 0.004 \mathrm{kGy}, 0.07 \mathrm{kGy}$ e $1 \mathrm{kGy}$, quando comparados ao controle apresentam diferenças, observa-se que a reta de LDA separou os dados e a acurácia, sensibilidade e especificidade estão representados na tabela 5 .

Tabela 5 - Sensibilidade , Especificidade e Acurácia da técnica de PCA/LDA apresentados na Figura 22

\begin{tabular}{lrrrrr}
\hline & $\begin{array}{c}\text { Controle } \\
\mathbf{0 . 0 0 2 k G y}\end{array}$ & $\begin{array}{r}\mathbf{X} \text { Controle } \\
\mathbf{0 . 0 0 4 k G y}\end{array}$ & $\begin{array}{r}\mathbf{X} \text { Controle } \\
\mathbf{0 . 0 7 k G y}\end{array}$ & $\begin{array}{l}\text { X Controle } \\
\text { 1kGy }\end{array}$ & $\mathbf{X}$ \\
\hline Sensibilidade & $75 \%$ & $82 \%$ & $70 \%$ & $77 \%$ & \\
Especificidade & $90 \%$ & $90 \%$ & $90 \%$ & $94 \%$ & \\
Acurácia & $83 \%$ & $86 \%$ & $80 \%$ & $86 \%$ & \\
\hline
\end{tabular}

Fonte: Autor da dissertação 
Figura 23 - PCA/LDA controle x 10kGy (A), PCA/LDA controle x15kGy (B), PCA/LDA controle $x$ $25 \mathrm{kGy}(\mathrm{C}), \mathrm{PCA} / \mathrm{LDA}$ controle $\times 35 \mathrm{kGy}(\mathrm{D})$
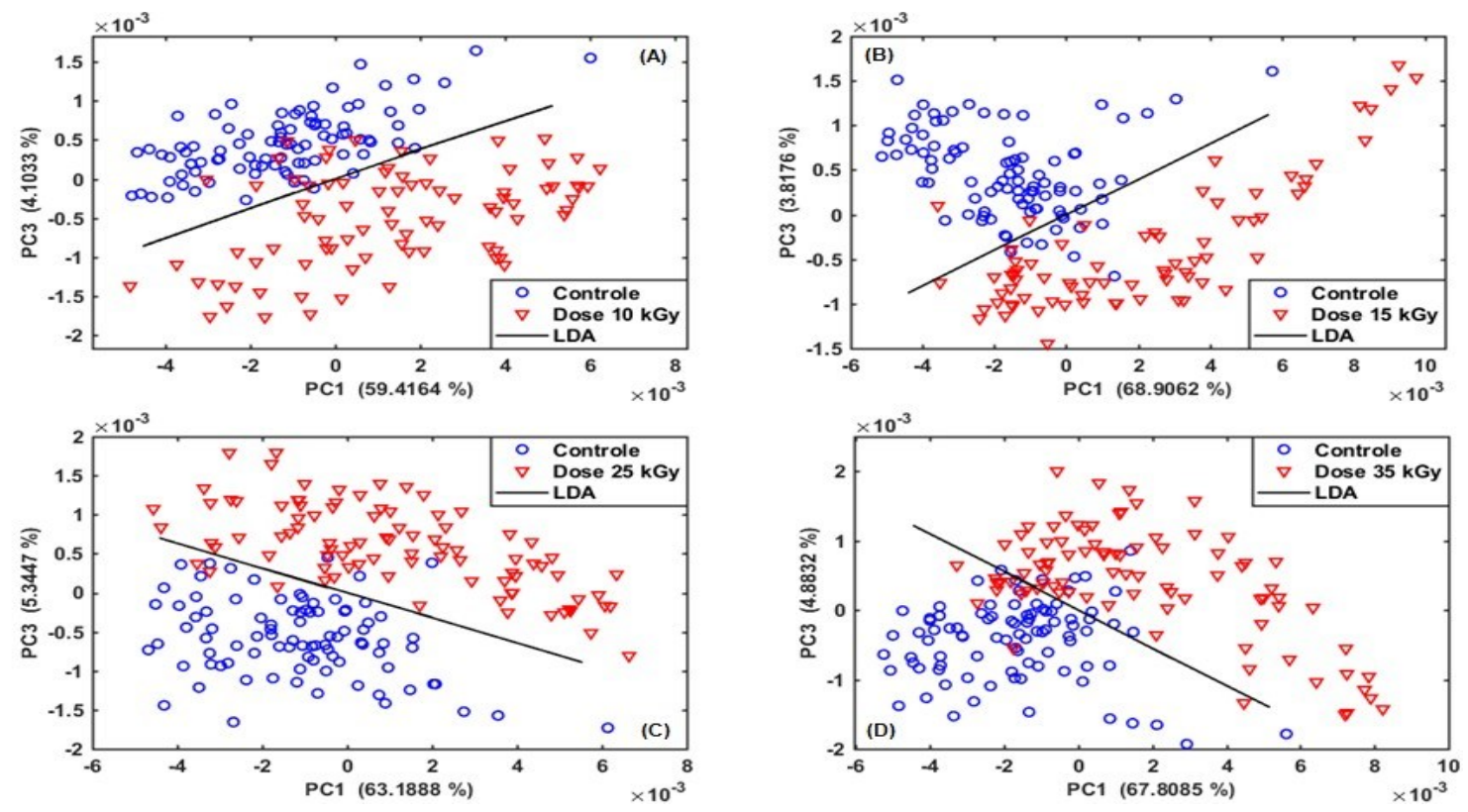

Fonte: Autor da dissertação

$\mathrm{Na}$ figura 23 os grupos de $10 \mathrm{kGy}, 15 \mathrm{kGy}, 25 \mathrm{kGy}$ e $35 \mathrm{kGy}$, quando comparados ao controle apresentam diferenças, observa-se que a reta de LDA separou os dados e a Acurácia, sensibilidade e especificidade estão representados na tabela 6 .

Tabela 6 - Sensibilidade, Especificidade e Acurácia da técnica de PCA/LDA apresentados na Figura 23

\begin{tabular}{lrrrrr}
\hline & $\begin{array}{l}\text { Controle } \\
\text { 10kGy }\end{array}$ & $\begin{array}{l}\text { X Controle } \\
\text { 15kGy }\end{array}$ & $\begin{array}{l}\text { X Controle } \\
\text { 25kGy }\end{array}$ & $\begin{array}{l}\text { X } \\
\text { 35kGy }\end{array}$ \\
\hline Sensibilidade & $85 \%$ & $98 \%$ & $97 \%$ & $87 \%$ \\
Especificidade & $98 \%$ & $88 \%$ & $97 \%$ & $89 \%$ \\
Acurácia & $92 \%$ & $93 \%$ & $97 \%$ & $89 \%$
\end{tabular}

Fonte: Autor da dissertação 
Figura 24 - PCA/LDA controle x 50kGy (A), PCA/LDA controle x60kGy (B)
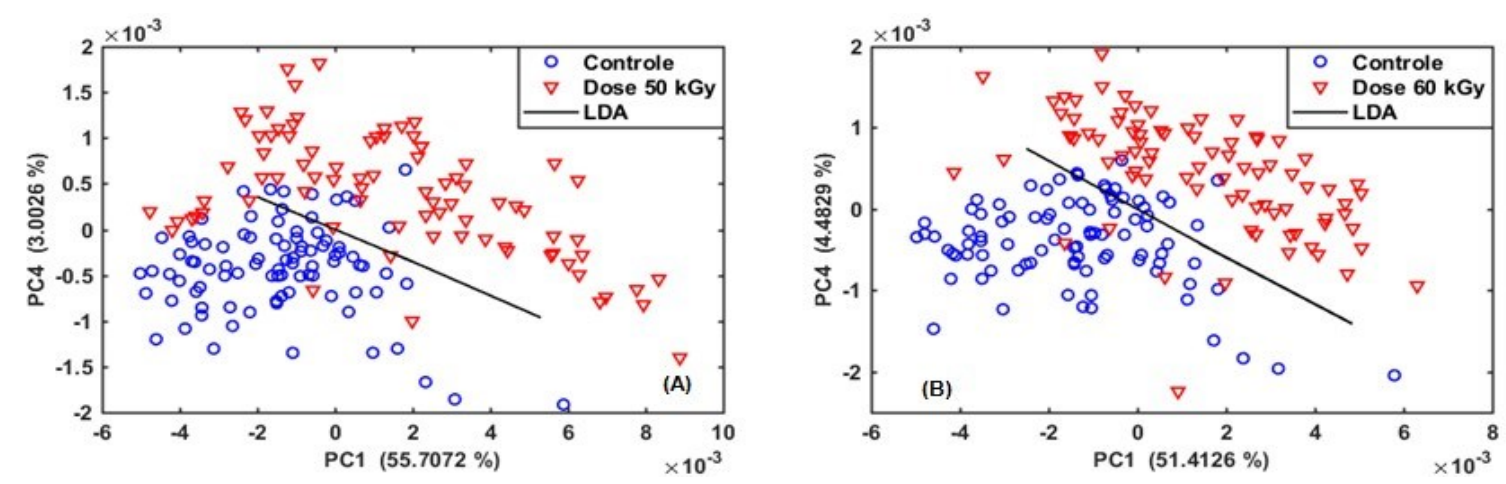

Fonte: Autor da dissertação

$\mathrm{Na}$ figura 24 os grupos de $50 \mathrm{kGy}$ e $60 \mathrm{kGy}$, quando comparados ao controle apresentam diferenças, observa-se que a reta de LDA separou os dados e a acurácia, sensibilidade e especificidade estão representados na tabela 7.

Tabela 7 - Sensibilidade, Especificidade e Acurácia da técnica de PCA/LDA apresentados na Figura 24

\begin{tabular}{lcc}
\hline & Controle x 50kGy & Controle x 60kGy \\
\hline Sensibilidade & $86 \%$ & $90 \%$ \\
Especificidade & $90 \%$ & $86 \%$ \\
Acurácia & $88 \%$ & $88 \%$ \\
\hline
\end{tabular}

Fonte: Autor da dissertação

A análise de PCA/LDA demonstra se há diferenças entre os grupos, no entanto, não demonstra qual componente está sendo afetado pela radiação, para isso é necessário realizar análise de proporção de área, para verificar onde estão essas diferenças. 


\section{2Área sob a curva da banda de Fosfato ${ }_{v 1, v 3} \mathrm{PO}_{4}^{3-}$}

Os resultados da análise de área da região relacionada à banda de Fosfato ${ }_{v 1, v 3} \mathrm{PO}_{4}^{3-}\left(900\right.$ a $1200 \mathrm{~cm}^{-1}$ ), que corresponde ao conteúdo mineral de maior intensidade no tecido ósseo são apresentados na figura 25.

Figura 25 - Área da banda relacionada ao conteúdo mineral na região de 900 a $1200 \mathrm{~cm}^{-1}$ normalizada vetorialmente.

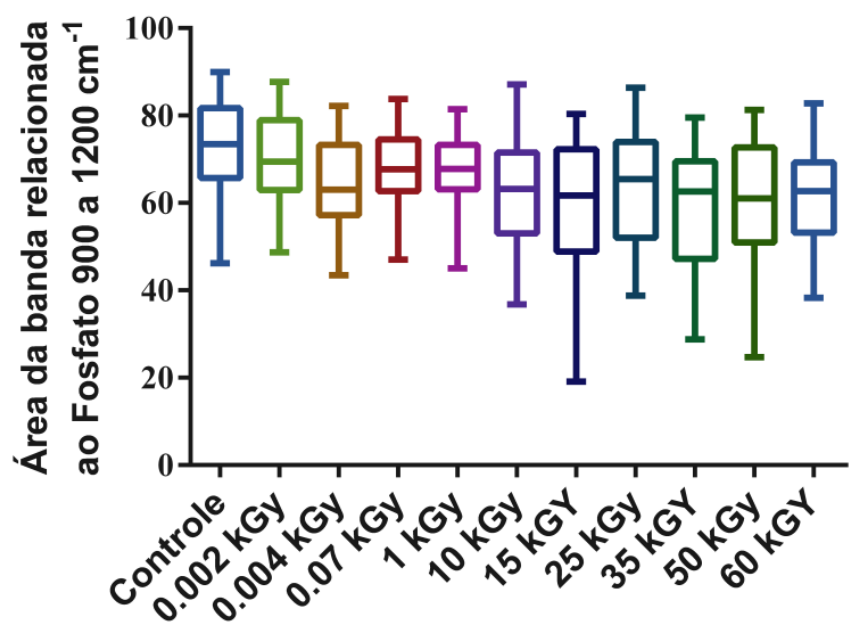

Fonte: Autor da dissertação

Observa-se diminuição nas áreas de Fosfato até 0.007 kGy (G3), de 0.07 kGy (G4) a 15 kGy (G7) e de 25 kGy (G8) a 50 kGy (G10), mas quando comparados ao controle, todos os grupos apresentam diminuição no cálculo de área de acordo com a dose de radiação aplicada.

O teste de Kruskal-Wallis aplicado com nível de significância de 0,05, resultou diferença estatística entre o grupo das amostras não irradiadas em relação aos grupos de amostras irradiadas com doses de 0.004 kGy, 10 kGy, 15 kGy, 25 kGy, 35 kGy, 50 kGy e 60 kGy, onde observamos que a radiação ionizante quando aplicada em doses baixas, com exceção da dose de 0.004 kGy (G3), não afetou a estrutura inorgânica do tecido em uma perspectiva de análise univariada. $O$ efeito da radiação no tecido foi observado apenas à partir da dose de 10 kGy. 
Estas diferenças são representadas na tabela 8 onde também foi possível verificar diferenças estatísticas obtidas entre alguns grupos irradiados.

Tabela 8 - Teste Kruskal - Wallis dos dados de área da banda de Fosfato ${ }_{v 1, v 3} \mathrm{PO}_{4}{ }^{3-}(900$ a $1200 \mathrm{~cm}^{-1}$ )

\begin{tabular}{c|ccccccccccc}
\hline $\mathbf{k G y}$ & $\mathbf{0}$ & $\mathbf{0 . 0 0 2}$ & $\mathbf{0 . 0 0 4}$ & $\mathbf{0 . 0 7}$ & $\mathbf{1}$ & $\mathbf{1 0}$ & $\mathbf{1 5}$ & $\mathbf{2 5}$ & $\mathbf{3 5}$ & $\mathbf{5 0}$ & $\mathbf{6 0}$ \\
\hline $\mathbf{0}$ & - & $* * * *$ & NS & NS & NS & $* * * *$ & $* * * *$ & $* * * *$ & $* * * *$ & $* * * *$ & $* * * *$ \\
$\mathbf{0 . 0 0 2}$ & $* * * *$ & - & $*$ & NS & NS & $* *$ & $* * * *$ & $*$ & $* * * *$ & $* * * *$ & $* * * *$ \\
$\mathbf{0 . 0 0 4}$ & - & - & - & NS & NS & NS & NS & NS & NS & NS & NS \\
$\mathbf{0 . 0 7}$ & NS & NS & $*$ & - & NS & NS & $* *$ & NS & $* * *$ & $* *$ & $* *$ \\
$\mathbf{1}$ & NS & NS & NS & NS & - & NS & $*$ & NS & $* *$ & $*$ & $*$ \\
$\mathbf{1 0}$ & $* * * *$ & $* *$ & NS & NS & NS & - & NS & NS & NS & NS & NS \\
$\mathbf{1 5}$ & $* * * *$ & $* * * *$ & NS & $* *$ & $*$ & NS & - & NS & NS & NS & NS \\
$\mathbf{2 5}$ & $* * * *$ & $*$ & NS & NS & NS & NS & NS & - & NS & NS & NS \\
35 & $* * * *$ & $* * * *$ & NS & $* * *$ & $* *$ & NS & NS & NS & - & NS & NS \\
$\mathbf{5 0}$ & $* * * *$ & $* * * *$ & NS & $* *$ & $*$ & NS & NS & NS & NS & - & NS \\
$\mathbf{6 0}$ & $* * * *$ & $* * * *$ & NS & $* *$ & $*$ & NS & NS & NS & NS & NS & - \\
\hline
\end{tabular}

Fonte: Autor da dissertação 


\section{3 Área sob a curva da banda de Amida I}

Os resultados da análise de área da região relacionada à banda de Amida I (1600 a $\left.1720 \mathrm{~cm}^{-1}\right)$ estão representados na figura 26. Esta região, segundo a literatura, está correlacionada ao colágeno tipo I, que é um dos principais e mais abundantes constituintes orgânicos do tecido ósseo ${ }^{40}$.

Figura 26 - Área da banda relacionada à Amida I de 1500 a $1800 \mathrm{~cm}-1$ normalizada vetorialmente.

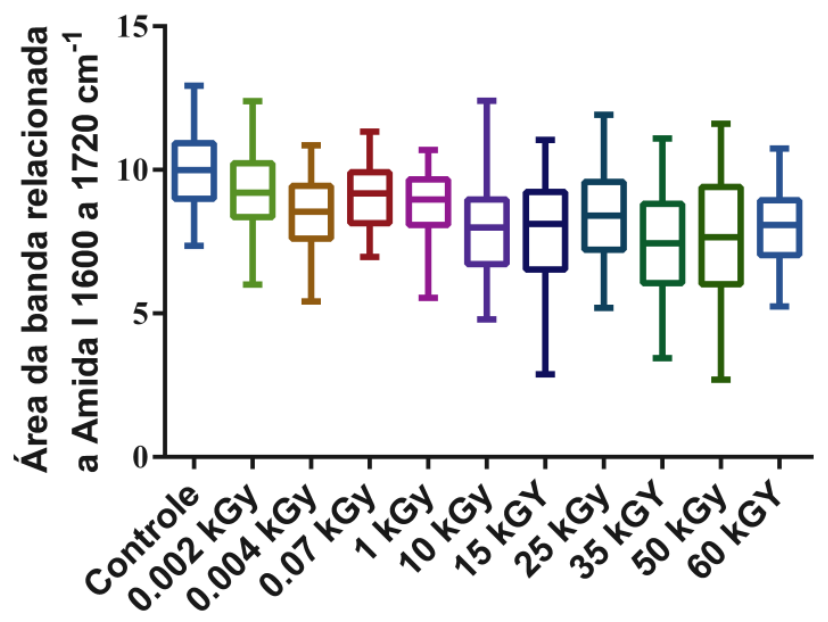

Fonte: Autor da dissertação

Observa-se diminuição nas áreas de Amida I até 0.007 kGy (G3), e diminuições de 0.07 kGy (G4) a 15 kGy (G7) e de 25 kGy (G8) a 50 kGy (G10), mas quando comparados ao controle, todos os grupos apresentaram diminuição no cálculo de área de acordo com a dose de radiação aplicada.

O teste de Kruskal-Wallis aplicado com nível de significância de 0,05, resultou diferença estatística entre o grupo das amostras não irradiadas em relação a todos os grupos de amostras irradiadas, com exceção do grupo irradiado com dose de 0,002 kGy (G2), onde observam-se os efeitos da radiação ionizante nos compostos orgânicos do tecido, afetando o tecido independente da dose aplicada.

Estas diferenças são representadas na Tabela 9 onde também é possível verificar as diferenças estatísticas obtidas entre alguns grupos irradiados. Onde 
há indicativos de degradação da banda de Amida I a partir da dose de 10 kGy (G6), pois não foi observada diferença estatística significante quando comparados aos grupos irradiados com doses mais elevadas, reforçando assim o que está descrito na literatura ${ }^{17,18,19}$

Tabela 9 - Kruskal - Wallis dos dados de área da banda de Amida I

\begin{tabular}{c|ccccccccccc}
\hline $\mathbf{k G y}$ & $\mathbf{0}$ & $\mathbf{0 . 0 0 2}$ & $\mathbf{0 . 0 0 4}$ & $\mathbf{0 . 0 7}$ & $\mathbf{1}$ & $\mathbf{1 0}$ & $\mathbf{1 5}$ & $\mathbf{2 5}$ & $\mathbf{3 5}$ & $\mathbf{5 0}$ & $\mathbf{6 0}$ \\
\hline $\mathbf{0}$ & - & NS & $* * * *$ & $*$ & $* * *$ & $* * * *$ & $* * * *$ & $* * * *$ & $* * * *$ & $* * * *$ & $* * * *$ \\
$\mathbf{0 . 0 0 2}$ & NS & - & NS & NS & NS & $* * * *$ & $* * * *$ & $*$ & $* * * *$ & $* * * *$ & $* * * *$ \\
$\mathbf{0 . 0 0 4}$ & $* * * *$ & NS & - & NS & NS & NS & NS & NS & $* *$ & NS & NS \\
$\mathbf{0 . 0 7}$ & $*$ & NS & NS & - & NS & $* * * *$ & $* * *$ & NS & $* * * *$ & $* * * *$ & $* * *$ \\
$\mathbf{1}$ & $* * *$ & NS & NS & NS & - & $* *$ & $*$ & NS & $* * * *$ & $* *$ & $*$ \\
10 & $* * * *$ & $* * * *$ & NS & $* * *$ & $* *$ & - & NS & NS & NS & NS & NS \\
$\mathbf{1 5}$ & $* * * *$ & $* * * *$ & NS & $* * *$ & $*$ & NS & - & NS & NS & NS & NS \\
$\mathbf{2 5}$ & $* * * *$ & $*$ & NS & NS & NS & NS & NS & - & NS & NS & NS \\
$\mathbf{3 5}$ & $* * * *$ & $* * * *$ & $* *$ & $* * * *$ & $* * * *$ & NS & NS & NS & - & NS & NS \\
$\mathbf{5 0}$ & $* * * *$ & $* * * *$ & NS & $* * * *$ & $* *$ & NS & NS & NS & NS & - & NS \\
$\mathbf{6 0}$ & $* * * *$ & $* * * *$ & NS & $*$ & NS & NS & NS & NS & NS & NS & - \\
\hline
\end{tabular}

Fonte: Autor da dissertação 


\section{4Área sob a curva da banda de Amida II}

Os resultados da análise de área da região relacionada à banda de Amida II (1480 a $1600 \mathrm{~cm}^{-1}$ ) estão representados na figura 27. Essa região está sobreposta a do Carbonato e também está correlacionada aos componentes proteicos do osso, principalmente colágeno tipo I ${ }^{48}$.

Figura 27 Área da banda relacionada a Amida II de 1480 a $1600 \mathrm{~cm}^{-1}$ normalizada vetorialmente.

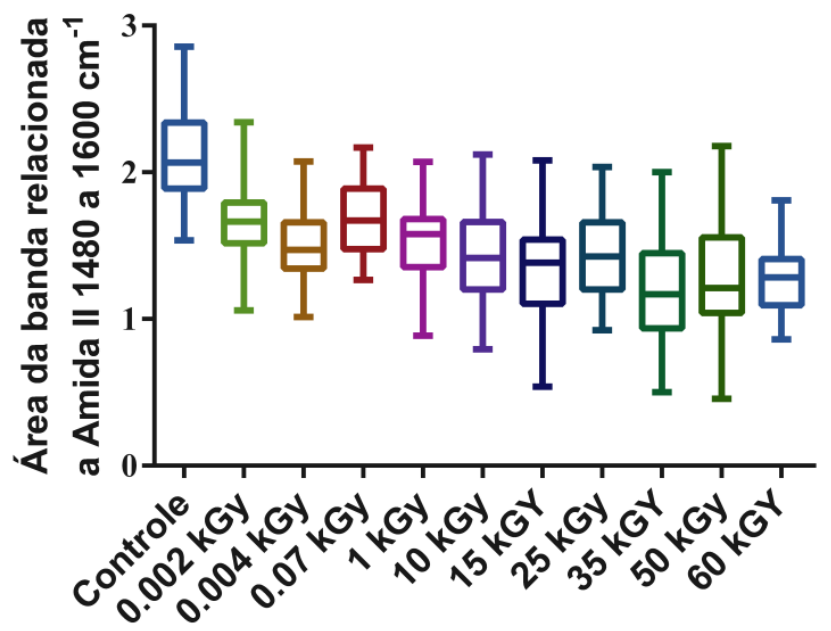

Fonte: Autor da dissertação

No grupo controle (G1), observou-se diminuição em relação a todos os grupos irradiados e diminuições entre os grupos irradiados até 0.004 kGy (G3), de 0.07 kGy (G4) a 15 kGy (G7), de 25 kGy (G8) a 35 kGy (G9) e de 50 kGy (G10) a 60 kGy (G11).

O teste de Kruskal-Wallis aplicado com nível de significância de 0,05, resultou diferença estatística entre o grupo das amostras não irradiadas em relação a todos os grupos de amostras irradiadas, onde observou-se os efeitos da radiação ionizante nos compostos orgânicos do tecido, afetando o tecido independente da dose aplicada.

Estas diferenças são representadas na Tabela 10 onde também é possível verificar as diferenças estatísticas entre os grupos irradiados. Onde houve indicativos de degradação da banda de Amida II a partir da dose de 10 kGy (G6), reforçando assim o que está descrito na literatura ${ }^{17,18,19}$. 
Tabela 10 Kruskal - Wallis dos dados de área da banda de Amida II

\begin{tabular}{c|ccccccccccc}
\hline kGy & $\mathbf{0}$ & $\mathbf{0 . 0 0 2}$ & $\mathbf{0 . 0 0 4}$ & $\mathbf{0 . 0 7}$ & $\mathbf{1}$ & $\mathbf{1 0}$ & $\mathbf{1 5}$ & $\mathbf{2 5}$ & $\mathbf{3 5}$ & $\mathbf{5 0}$ & $\mathbf{6 0}$ \\
\hline $\mathbf{0}$ & - & $* * * *$ & $* * * *$ & $* * * *$ & $* * * *$ & $* * * *$ & $* * * *$ & $* * * *$ & $* * * *$ & $* * * *$ & $* * * *$ \\
$\mathbf{0 . 0 0 2}$ & $* * * *$ & - & NS & NS & NS & $* * *$ & $* * * *$ & $* * *$ & $* * * *$ & $* * * *$ & $* * * *$ \\
$\mathbf{0 . 0 0 4}$ & $* * * *$ & NS & - & $* *$ & NS & NS & NS & NS & $* * * *$ & $*$ & $* * *$ \\
$\mathbf{0 . 0 7}$ & $* * * *$ & NS & $* *$ & - & NS & $* * * *$ & $* * * *$ & $* * * *$ & $* * * *$ & $* * * *$ & $* * * *$ \\
1 & $* * * *$ & NS & NS & NS & - & NS & $*$ & NS & $* * * *$ & $* * *$ & $* * * *$ \\
10 & $* * * *$ & $* * *$ & NS & $* * * *$ & NS & - & NS & NS & $* *$ & NS & $*$ \\
15 & $* * * *$ & $* * * *$ & NS & $* * * *$ & $*$ & NS & - & NS & NS & NS & NS \\
25 & $* * * *$ & $* * *$ & NS & $* * * *$ & NS & NS & NS & - & $* *$ & NS & $*$ \\
35 & $* * * *$ & $* * * *$ & $* * * *$ & $* * * *$ & $* * * *$ & $* *$ & NS & $* *$ & - & NS & NS \\
50 & $* * * *$ & $* * * *$ & $*$ & $* * * *$ & $* * *$ & NS & NS & NS & NS & - & NS \\
60 & $* * * *$ & $* * * *$ & $* * *$ & $* * * *$ & $* * * *$ & $*$ & NS & $*$ & NS & NS & - \\
\hline
\end{tabular}

Fonte: Autor da dissertação 


\section{5 Área sob a curva da banda de Amida III}

Os resultados da análise de área da região relacionada à banda de Amida III (1200 a $1350 \mathrm{~cm}^{-1}$ ) estão representados na figura 28., região essa que segundo a Tabela 2 está diretamente relacionada ao Colágeno 48

Figura 28 --Área da banda relacionada a Amida III de 1200 a $1350 \mathrm{~cm}-1$ normalizada vetorialmente.

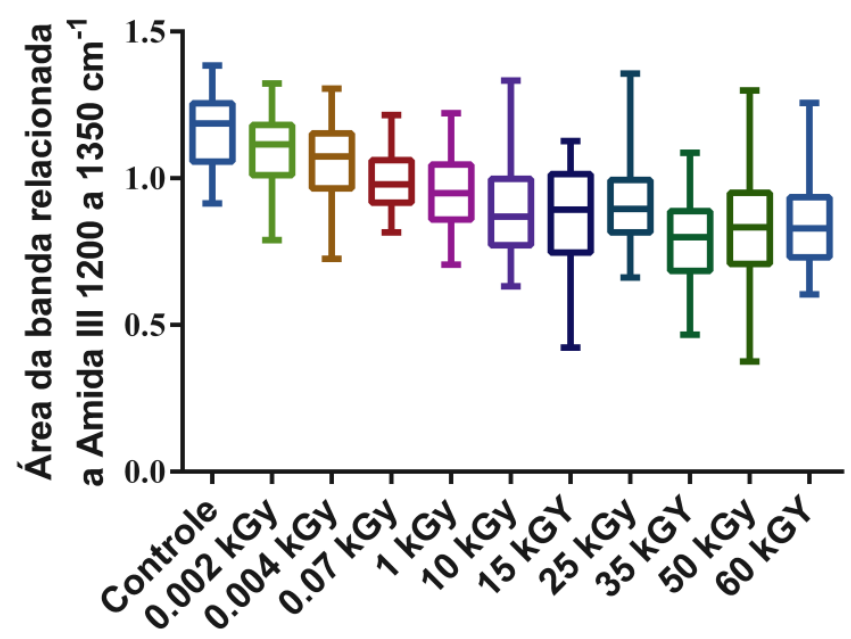

Fonte: Autor da dissertação

No grupo controle (G1), observou-se diminuição em relação a todos os grupos irradiados e diminuições entre os grupos irradiados até $15 \mathrm{kGy}(\mathrm{G} 7)$ e de 25 kGy (G8) a 35 kGy (G9).

O teste de Kruskal-Wallis aplicado com nível de significância de 0,05, resultou diferença estatística entre o grupo das amostras não irradiadas em relação a todos os grupos de amostras irradiadas a partir de 0.07 kGy (G4), onde observou-se os efeitos da radiação ionizante nos compostos orgânicos do tecido, afetando o tecido independente da dose aplicada.

Estas diferenças são representadas na Tabela 11 onde também é possível verificar as diferenças estatísticas obtidas entre alguns grupos irradiados. Onde houve indicativos de degradação da banda de Amida III a partir da dose de 10 kGy (G6), com exceção do grupo irradiado com 25 kGy (G8) em relação ao grupo irradiado com $35 \mathrm{kGy}(\mathrm{G} 9)$, reforçando assim o que está descrito na literatura ${ }^{17,18,19}$. 
Tabela 11 Kruskal - Wallis dos dados de área da banda de Amida III

\begin{tabular}{c|ccccccccccc}
\hline $\mathbf{k G y}$ & $\mathbf{0}$ & $\mathbf{0 . 0 0 2}$ & $\mathbf{0 . 0 0 4}$ & $\mathbf{0 . 0 7}$ & $\mathbf{1}$ & $\mathbf{1 0}$ & $\mathbf{1 5}$ & $\mathbf{2 5}$ & $\mathbf{3 5}$ & $\mathbf{5 0}$ & $\mathbf{6 0}$ \\
\hline $\mathbf{0}$ & - & NS & NS & $* * * *$ & $* * * *$ & $* * * *$ & $* * * *$ & $* * * *$ & $* * * *$ & $* * * *$ & $* * * *$ \\
$\mathbf{0 . 0 0 2}$ & NS & - & NS & $*$ & $* * * *$ & $* * * *$ & $* * * *$ & $* * * *$ & $* * * *$ & $* * * *$ & $* * * *$ \\
$\mathbf{0 . 0 0 4}$ & NS & NS & - & NS & $* * *$ & $* * * *$ & $* * * *$ & $* * * *$ & $* * * *$ & $* * * *$ & $* * * *$ \\
$\mathbf{0 . 0 7}$ & $* * * *$ & $*$ & NS & - & NS & $* * *$ & $* * * *$ & $*$ & $* * * *$ & $* * * *$ & $* * * *$ \\
1 & $* * * *$ & $* * * *$ & $* * *$ & NS & - & NS & NS & NS & $* * * *$ & $* *$ & $* * *$ \\
10 & $* * * *$ & $* * * *$ & $* * * *$ & $* * *$ & NS & - & NS & NS & NS & NS & NS \\
15 & $* * * *$ & $* * * *$ & $* * * *$ & $* * * *$ & NS & NS & - & NS & NS & NS & NS \\
25 & $* * * *$ & $* * * *$ & $* * * *$ & $*$ & NS & NS & NS & - & $* * *$ & NS & NS \\
35 & $* * * *$ & $* * * *$ & $* * * *$ & $* * * *$ & $* * * *$ & NS & NS & $* * *$ & - & NS & NS \\
50 & $* * * *$ & $* * * *$ & $* * * *$ & $* * * *$ & $* *$ & NS & NS & NS & NS & - & NS \\
60 & $* * * *$ & $* * * *$ & $* * * *$ & $* * * *$ & $* * *$ & NS & NS & NS & NS & NS & - \\
\hline
\end{tabular}

Fonte: Autor da dissertação 


\section{6 Área sob a curva da banda de Colágeno}

Os resultados da análise de área da região relacionada a banda de colágeno (1140 a $1240 \mathrm{~cm}^{-1}$ ), estão representados na Figura 25.

\section{Figura 29 - Área da banda relacionada ao Colágeno de 1140 a $1240 \mathrm{~cm}^{-1}$ normalizada} vetorialmente

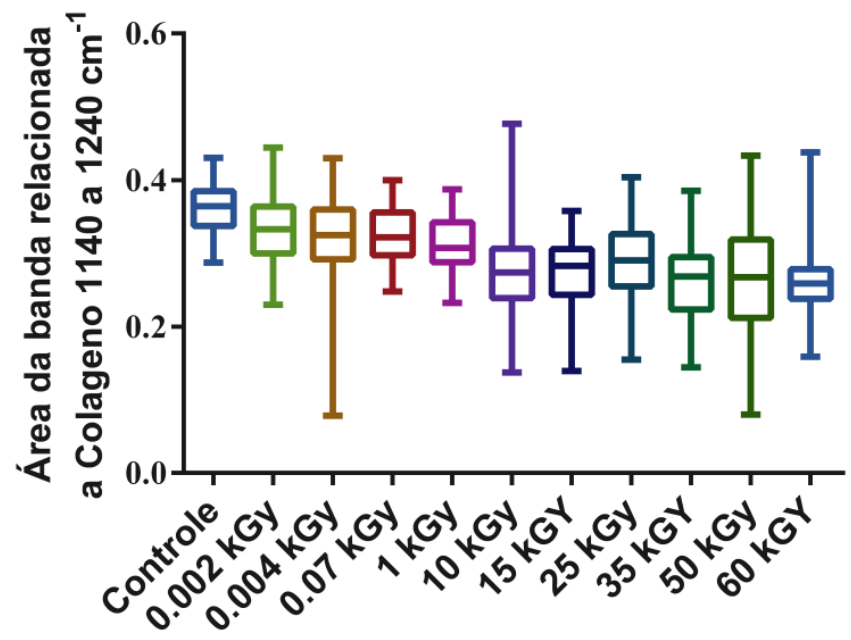

Fonte: Autor da dissertação

No grupo controle (G1), observou-se diminuição em relação a todos os grupos irradiados e diminuições entre os grupos irradiados até $0.004 \mathrm{kGy}(\mathrm{G} 3)$, de 0.07 kGy (G4) a 15 kGy (G7) e de 25 kGy (G8) a 50 kGy (G11).

O teste de Kruskal-Wallis aplicado com nível de significância de 0,05, resultou diferença estatística entre o grupo das amostras não irradiadas em relação a todos os grupos de amostras irradiadas, onde observou-se que as doses de radiação, na matriz orgânica do tecido ósseo, podem causar danos no colágeno, podendo diminuir sua proporção em até dois terços, afetando o tecido independente da dose aplicada ${ }^{36,37}$.

Estas diferenças são representadas na Tabela 12, onde também é possível verificar as diferenças estatísticas entre os grupos irradiados. Onde houve indicativos de degradação da banda de Colágeno, a partir da dose de 10 kGy (G6), com exceção do grupo irradiado com 25 kGy (G8) em relação ao grupo 
irradiado com 60 kGy (G11), reforçando assim o que está descrito na literatura ${ }^{17,18,19}$.

Tabela 12 Kruskal - Wallis dos dados de área da banda de Colágeno

\begin{tabular}{c|ccccccccccc}
\hline $\mathbf{k G y}$ & $\mathbf{0}$ & $\mathbf{0 . 0 0 2}$ & $\mathbf{0 . 0 0 4}$ & $\mathbf{0 . 0 7}$ & $\mathbf{1}$ & $\mathbf{1 0}$ & $\mathbf{1 5}$ & $\mathbf{2 5}$ & $\mathbf{3 5}$ & $\mathbf{5 0}$ & $\mathbf{6 0}$ \\
\hline $\mathbf{0}$ & - & $*$ & $* * *$ & $* *$ & $* * * *$ & $* * * *$ & $* * * *$ & $* * * *$ & $* * * *$ & $* * * *$ & $* * * *$ \\
$\mathbf{0 . 0 0 2}$ & $*$ & - & NS & NS & NS & $* * * *$ & $* * * *$ & $* * * *$ & $* * * *$ & $* * * *$ & $* * * *$ \\
$\mathbf{0 . 0 0 4}$ & $* * *$ & NS & - & NS & NS & $* * * *$ & $* * * *$ & $* *$ & $* * * *$ & $* * * *$ & $* * * *$ \\
$\mathbf{0 . 0 7}$ & $* *$ & NS & NS & - & NS & $* * * *$ & $* * * *$ & $* * * *$ & $* * * *$ & $* * * *$ & $* * * *$ \\
1 & $* * * *$ & NS & NS & $* * * *$ & - & $* * *$ & $* * *$ & NS & $* * * *$ & $* * * *$ & $* * * *$ \\
10 & $* * * *$ & $* * * *$ & $* * * *$ & $* * * *$ & $* * *$ & - & NS & NS & NS & NS & NS \\
15 & $* * * *$ & $* * * *$ & $* * * *$ & $* * * *$ & $* * *$ & NS & - & NS & NS & NS & NS \\
25 & $* * * *$ & $* * * *$ & $* *$ & $* * * *$ & NS & NS & NS & - & NS & NS & $* *$ \\
35 & $* * * *$ & $* * * *$ & $* * * *$ & $* * * *$ & $* * * *$ & NS & NS & NS & - & NS & NS \\
50 & $* * * *$ & $* * * *$ & $* * * *$ & $* * * *$ & $* * * *$ & NS & NS & NS & NS & - & NS \\
60 & $* * * *$ & $* * * *$ & $* * * *$ & $* * * *$ & $* * * *$ & NS & NS & $* *$ & NS & NS & - \\
\hline
\end{tabular}

Fonte: Autor da dissertação 


\section{7 Área sob a curva da banda de Carbonato}

. Os resultados da análise de área da região relacionada a banda de Carbonato v2 $\left(\mathrm{CO}_{3}{ }^{2-}\right)\left(1200\right.$ a $\left.1550 \mathrm{~cm}^{-1}\right)$ estão representados na Figura 30, um dos componentes que formam os cristais de hidroxiapatita ${ }^{42}$.

Figura 30 - Área da banda relacionada a Carbonato de 1200 a $1550 \mathrm{~cm}^{-1}$ normalizada vetorialmente

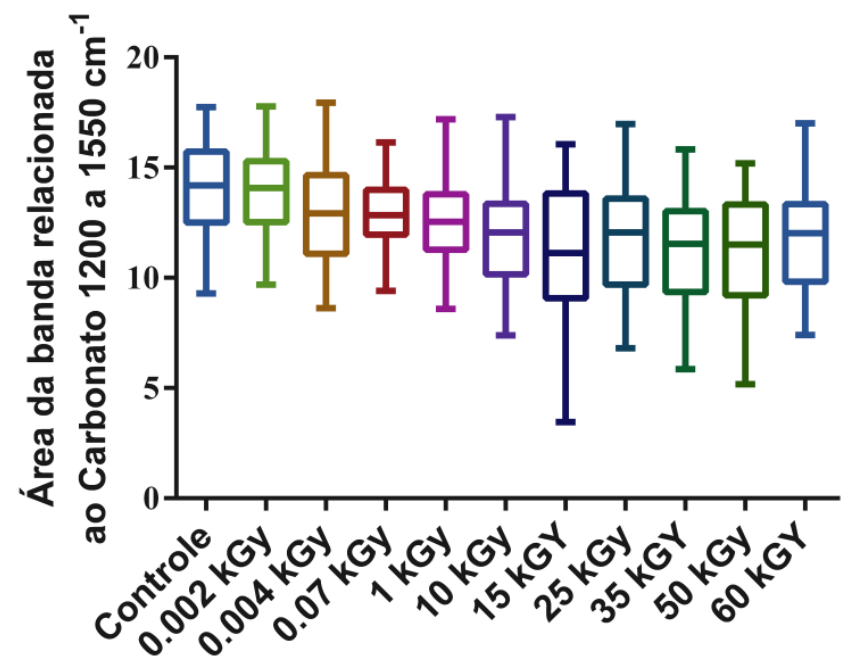

Fonte: Autor da dissertação

No grupo controle (G1), observou-se diminuição em relação a todos os grupos irradiados e diminuições entre os grupos irradiados até $0.004 \mathrm{kGy}(\mathrm{G} 3) \mathrm{e}$ de 0.07 kGy (G4) a 15 kGy (G7) e de 25 kGy (G8) a 50 kGy (G10).

O teste de Kruskal-Wallis aplicado com nível de significância de 0,05 , resultou diferença estatística entre o grupo das amostras não irradiadas em relação a todos os grupos de amostras irradiadas a partir de 1 kGy (G5), onde observa-se os efeitos da radiação ionizante nos compostos inorgânicos do tecido.

Estas diferenças são representadas na Tabela 13. Onde também é possível verificar as diferenças estatísticas entre alguns grupos irradiados. 
Tabela 13 - Kruskal - Wallis dos dados de área da banda de Carbonato

\begin{tabular}{c|ccccccccccc}
\hline $\mathbf{k G y}$ & $\mathbf{0}$ & $\mathbf{0 . 0 0 2}$ & $\mathbf{0 . 0 0 4}$ & $\mathbf{0 . 0 7}$ & $\mathbf{1}$ & $\mathbf{1 0}$ & $\mathbf{1 5}$ & $\mathbf{2 5}$ & $\mathbf{3 5}$ & $\mathbf{5 0}$ & $\mathbf{6 0}$ \\
\hline $\mathbf{0}$ & - & NS & $*$ & NS & $* * *$ & $* * * *$ & $* * * *$ & $* * * *$ & $* * * *$ & $* * * *$ & $* * * *$ \\
$\mathbf{0 . 0 0 2}$ & NS & - & NS & NS & $* *$ & $* * * *$ & $* * * *$ & $* * * *$ & $* * * *$ & $* * * *$ & $* * * *$ \\
$\mathbf{0 . 0 0 4}$ & $*$ & NS & - & NS & NS & NS & $*$ & NS & $* *$ & $* *$ & NS \\
$\mathbf{0 . 0 7}$ & NS & NS & NS & - & NS & NS & $* *$ & NS & $* * *$ & $* *$ & NS \\
$\mathbf{1}$ & $* * *$ & $* *$ & NS & NS & - & NS & NS & NS & NS & NS & NS \\
$\mathbf{1 0}$ & $* * * *$ & $* * * *$ & NS & NS & NS & - & NS & NS & NS & NS & NS \\
$\mathbf{1 5}$ & $* * * *$ & $* * * *$ & $*$ & $* *$ & NS & NS & - & NS & NS & NS & NS \\
$\mathbf{2 5}$ & $* * * *$ & $* * * *$ & NS & NS & NS & NS & NS & - & NS & NS & NS \\
$\mathbf{3 5}$ & $* * * *$ & $* * * *$ & $* *$ & $* * *$ & NS & NS & NS & NS & - & NS & NS \\
$\mathbf{5 0}$ & $* * * *$ & $* * * *$ & $* *$ & $* *$ & NS & NS & NS & NS & NS & - & NS \\
$\mathbf{6 0}$ & $* * * *$ & $* * * *$ & NS & NS & NS & NS & NS & NS & NS & NS & - \\
\hline
\end{tabular}

Fonte: Autor da dissertação 


\subsection{Análise de Índice de Cristalinidade}

O Índice de cristalinidade (IC) é uma medida da ordem dos cristais, da tensão e da organização no osso, A cristalinidade não é uniforme em todo o esqueleto, e varia entre os diferentes tecidos mineralizados do corpo humano, Em muitos aspectos, o índice de cristalinidade poderia ser visto como uma medida "média" de mudança mineral induzida pela radiação, podendo prejudicar a formação óssea, diminuindo a proliferação e diferenciação dos osteoblastos, induzindo assim, à parada do ciclo celular, contribuindo na redução da densidade mineral óssea após a irradiação ${ }^{49}$ Os resultados de análise de índice Cristalinidade calculados a partir da banda de Fosfato $v_{v 4} \mathrm{PO}_{4}^{3-}$ estão representados na Figura 31.

Figura 31 - Índice de cristalinidade, calculados a partir da banda de Fosfato $v_{4} \mathrm{PO}_{4}{ }^{3}$

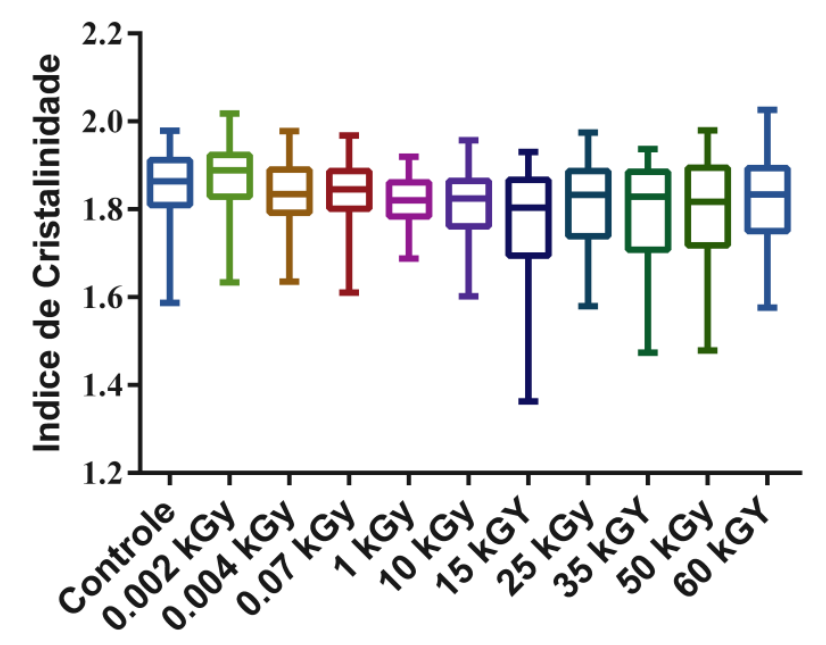

Fonte: Autor da dissertação

No grupo controle (G1) observou-se um aumento em relação ao grupo irradiado com $0.002 \mathrm{kGy}(\mathrm{G} 2)$, diminuição em relação ao grupo de $0.004 \mathrm{kGy}$ (G3), aumenta em $0.07 \mathrm{kGy}$, diminui até o grupo irradiado com $15 \mathrm{kGy}(\mathrm{G} 7)$, aumenta em $25 \mathrm{kGy}$ (G8), diminui em $35 \mathrm{kGy}$ (G9) e aumenta ate o grupo irradiado com $60 \mathrm{kGy}(\mathrm{G} 11)$.

O teste de Kruskal-Wallis aplicado com nível de significância de 0,05, resultou diferença estatística entre o grupo das amostras não irradiadas com os 
grupos irradiados com 10 kGy (G6), 15 kGy (G7) e 35 kGy (G9). Indicando alteração no índice cristalino, indicativo de alteração na qualidade óssea, conforme descrito na literatura. Os resultados de cristalinidade reforçam os resultados de análise de área da banda de Fosfato $v_{4} \mathrm{PO}_{4}^{3}(900$ a $1200 \mathrm{~cm}-1)$ que demonstraram diferença estatística a partir de 10kGy.

Estas diferenças são representadas na Tabela 14. Onde também é possível verificar as diferenças estatísticas entre os grupos irradiados. O grupo irradiado com 0.002 kGy (G2) observou-se diferença estatística em relação a todos os grupos irradiados e a partir do grupo irradiado com 0.004 kGy (G3) não há diferença estatística entre os grupos irradiados, indicando que não há alteração na qualidade óssea.

Tabela 14 - Kruskal - Wallis dos dados de análise de Cristalinidade

\begin{tabular}{c|ccccccccccc}
\hline kGy & $\mathbf{0}$ & $\mathbf{0 . 0 0 2}$ & $\mathbf{0 . 0 0 4}$ & $\mathbf{0 . 0 7}$ & $\mathbf{1}$ & $\mathbf{1 0}$ & $\mathbf{1 5}$ & $\mathbf{2 5}$ & $\mathbf{3 5}$ & $\mathbf{5 0}$ & $\mathbf{6 0}$ \\
\hline $\mathbf{0}$ & - & NS & NS & NS & NS & $*$ & $* * *$ & NS & $*$ & NS & NS \\
$\mathbf{0 . 0 0 2}$ & NS & - & $*$ & $* * * *$ & $* * * *$ & $* * * *$ & $* * *$ & $* * *$ & $* * * *$ & $* * *$ & $* *$ \\
$\mathbf{0 . 0 0 4}$ & NS & $*$ & - & NS & NS & NS & NS & NS & NS & NS & NS \\
$\mathbf{0 . 0 7}$ & NS & $* * * *$ & NS & - & NS & NS & $* *$ & NS & NS & NS & NS \\
$\mathbf{1}$ & NS & $* * * *$ & NS & NS & - & NS & NS & NS & NS & NS & NS \\
$\mathbf{1 0}$ & $*$ & $* * * *$ & NS & NS & NS & - & NS & NS & NS & NS & NS \\
$\mathbf{1 5}$ & $* * * *$ & $* * * *$ & NS & $* *$ & NS & NS & - & NS & NS & NS & NS \\
$\mathbf{2 5}$ & NS & $* * *$ & NS & NS & NS & NS & NS & - & NS & NS & NS \\
$\mathbf{3 5}$ & $*$ & $* * * *$ & NS & NS & NS & NS & NS & NS & - & NS & NS \\
$\mathbf{5 0}$ & NS & $* * *$ & NS & NS & NS & NS & NS & NS & NS & - & NS \\
$\mathbf{6 0}$ & NS & $* *$ & NS & NS & NS & NS & NS & NS & NS & NS & - \\
\hline
\end{tabular}

$$
\text { NS = Não significativo } \quad \text { * Significativo }(0,05)
$$

Fonte: Autor da dissertação 


\subsection{Razão da área de Amida I + Amida II/Fosfato}

A área integrada sob uma banda de absorção no infravermelho é diretamente proporcional à quantidade de espécies que gera a banda. Como resultado, a proporção da área integrada de Amida I + Amida II pelo Fosfato representa a quantidade de mineral normalizado para a quantidade de colágeno presente ${ }^{37}$. Os resultados da razão da área integrada de Amida I + Amida II (1480 a $\left.1800 \mathrm{~cm}^{-1}\right)$ pela área do Fosfato ${ }_{v 1, v 3} \mathrm{PO}_{4}{ }^{3-}\left(900\right.$ a $\left.1200 \mathrm{~cm}^{-1}\right)$ são apresentados na Figura 32.

Figura 32 Razão da área integrada de Amida I + Amida II (1480 a $\left.1800 \mathrm{~cm}^{-1}\right)$ pela área do Fosfato ${ }_{v 1, v 3} \mathrm{PO}_{4}^{3-}\left(900\right.$ a $\left.1200 \mathrm{~cm}^{-1}\right)$

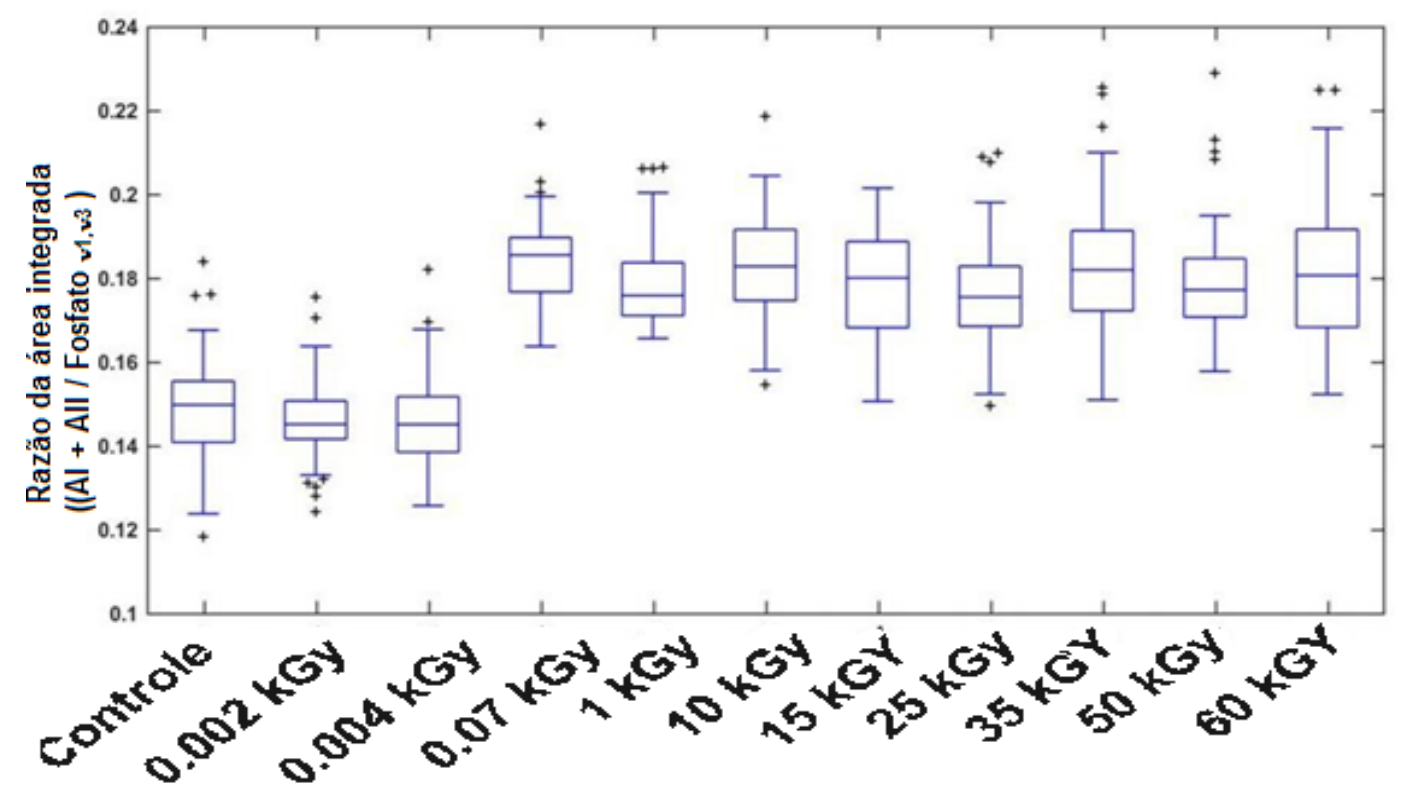

Fonte - Autor da dissertação

No grupo Controle observou-se um aumento em relação a todos os grupos irradiados a partir de 0.07 kGy, indicando que alteração na parcela orgânica (Amida I + Amida II) e inorgânica do tecido.

O teste de Kruskal-Wallis aplicado com nível de significância de 0,05, resultou diferença estatística entre o grupo das amostras não irradiadas com todos os grupos irradiados a partir de 0,04 kGy (G2).

Estas diferenças são representadas na Tabela 15. Onde também é possível verificar as diferenças estatísticas entre alguns grupos irradiados e a 
partir do grupo irradiado com 0.07 kGy (G4) não há diferença estatística entre os grupos irradiados.

Tabela 15 - Kruskal - Wallis dos dados de Razão da área integrada de Amida I + Amida II (1480 a $\left.1800 \mathrm{~cm}^{-1}\right)$ pela área do Fosfato ${ }_{v 1, v 3} \mathrm{PO}_{4}{ }^{3-}\left(900\right.$ a $\left.1200 \mathrm{~cm}^{-1}\right)$

\begin{tabular}{c|ccccccccccc}
\hline $\mathbf{k G y}$ & $\mathbf{0}$ & $\mathbf{0 . 0 0 2}$ & $\mathbf{0 . 0 0 4}$ & $\mathbf{0 . 0 7}$ & $\mathbf{1}$ & $\mathbf{1 0}$ & $\mathbf{1 5}$ & $\mathbf{2 5}$ & $\mathbf{3 5}$ & $\mathbf{5 0}$ & $\mathbf{6 0}$ \\
\hline $\mathbf{0}$ & - & NS & $* * * *$ & $* * * *$ & $* * * *$ & $* * * *$ & $* * * *$ & $* * * *$ & $* * * *$ & $* * * *$ & $* * * *$ \\
$\mathbf{0 . 0 0 2}$ & NS & - & NS & NS & $* * * *$ & $*$ & $* * * *$ & $* * * *$ & $* *$ & $* * * *$ & $* * * *$ \\
$\mathbf{0 . 0 0 4}$ & $* * * *$ & NS & - & NS & $* * * *$ & $*$ & $* * * *$ & $* * * *$ & $* *$ & $* * * *$ & $* * * *$ \\
$\mathbf{0 . 0 7}$ & $* * * *$ & NS & NS & - & NS & NS & NS & $* *$ & NS & NS & NS \\
$\mathbf{1}$ & $* * * *$ & $* * * *$ & $* * * *$ & NS & - & NS & NS & NS & NS & NS & NS \\
$\mathbf{1 0}$ & $* * * *$ & $*$ & $*$ & NS & NS & - & NS & $*$ & NS & NS & NS \\
$\mathbf{1 5}$ & $* * * *$ & $* * * *$ & $* * * *$ & NS & NS & NS & - & NS & NS & NS & NS \\
$\mathbf{2 5}$ & $* * * *$ & $* * * *$ & $* * * *$ & $* *$ & NS & $*$ & NS & - & NS & NS & NS \\
$\mathbf{3 5}$ & $* * * *$ & $* *$ & $* *$ & NS & NS & NS & NS & NS & - & NS & NS \\
$\mathbf{5 0}$ & $* * * *$ & $* * * *$ & $* * * *$ & NS & NS & NS & NS & NS & NS & - & NS \\
$\mathbf{6 0}$ & $* * * *$ & $* * * *$ & $* * * *$ & NS & NS & NS & NS & NS & NS & NS & - \\
\hline
\end{tabular}

Fonte - autor da dissertação

$$
\text { NS = Não significativo } \quad \text { * Significativo }(P<0,05)
$$




\subsection{Razão da área de Carbonato/Fosfato}

A área integrada sob uma banda de absorção no infravermelho é diretamente proporcional á quantidade de espécies que gera aquela determinada banda. Como resultado, a proporção da área da banda do Carbonato pela área da banda do Fosfato é atribuída a mudanças na composição estrutural dos cristais de hidroxiapatita maduros. Os resultados da razão da área de Carbonato ${ }_{v 2}\left(\mathrm{CO}_{3}{ }^{2-}\right)\left(1200\right.$ a $\left.1550 \mathrm{~cm}^{-1}\right)$ pelo Fosfato $(900 \mathrm{a}$ $1200 \mathrm{~cm}^{-1}$ ) são apresentados na Figura 33

Figura 33 Os resultados da razão da área de Carbonato $\left(1200\right.$ a $\left.1550 \mathrm{~cm}^{-1}\right)$ pelo Fosfato $(900$ a $1200 \mathrm{~cm}^{-1}$ )

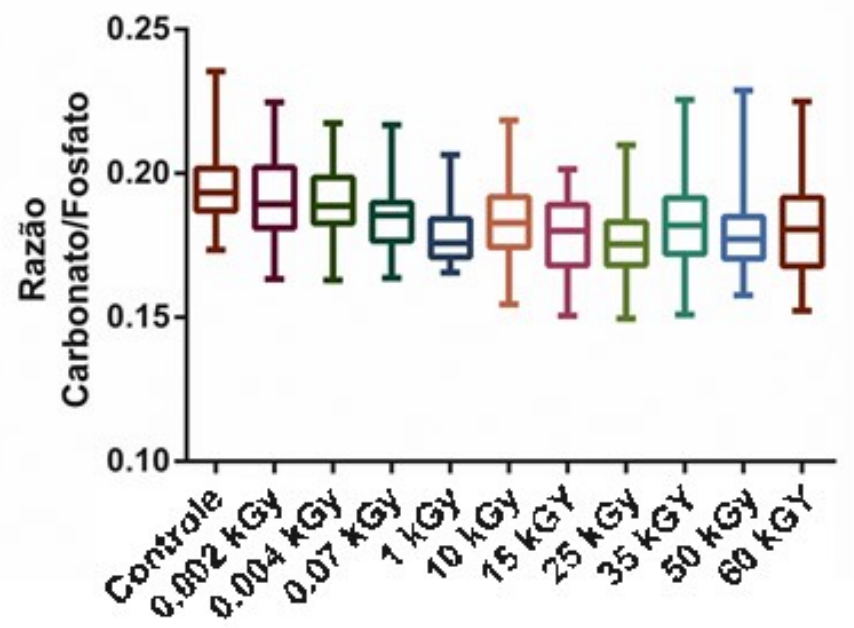

Fonte - Autor da Dissertação

No grupo Controle observou-se um aumento em relação ao grupo irradiado com $0.002 \mathrm{kGy}(\mathrm{G} 2)$, diminuição até $1 \mathrm{kGy}(\mathrm{G} 5)$, de $10 \mathrm{kGy}(\mathrm{G} 6)$ até 25 kGy (G8) e entre 35 kGy (G9) e 50 kGy (G10).

O teste de Kruskal-Wallis aplicado com nível de significância de 0,05, resultou diferença estatística entre o grupo das amostras não irradiadas com todos os grupos irradiados a partir de 0,07 kGy, indicando alteração na estrutura inorgânica do tecido.

Os resultados da razão de áreas de conteúdo inorgânico estão representados na Tabela 16 onde também é possível verificar as diferenças estatísticas obtidas entre alguns grupos irradiados, nos quais não houve 
indicativos de mudanças na composição estrutural da hidroxiapatita, a partir da dose de 0,07 kGy (G4).

Tabela 16 - Kruskal - Wallis dos dados de área da banda de Fosfato

\begin{tabular}{c|ccccccccccc}
\hline $\mathbf{k G y}$ & $\mathbf{0}$ & $\mathbf{0 . 0 0 2}$ & $\mathbf{0 . 0 0 4}$ & $\mathbf{0 . 0 7}$ & $\mathbf{1}$ & $\mathbf{1 0}$ & $\mathbf{1 5}$ & $\mathbf{2 5}$ & $\mathbf{3 5}$ & $\mathbf{5 0}$ & $\mathbf{6 0}$ \\
\hline $\mathbf{0}$ & - & NS & NS & $* * * *$ & $* * * *$ & $* * * *$ & $* * * *$ & $* * * *$ & $* * * *$ & $* * * *$ & $* * * *$ \\
$\mathbf{0 . 0 0 2}$ & NS & - & NS & NS & $* * * *$ & $*$ & $* * * *$ & $* * * *$ & $* *$ & $* * * *$ & $* * * *$ \\
$\mathbf{0 . 0 0 4}$ & NS & NS & - & NS & $* * * *$ & $*$ & $* * * *$ & $* * * *$ & $* *$ & $* * * *$ & $* * * *$ \\
$\mathbf{0 . 0 7}$ & $* * * *$ & NS & NS & - & NS & NS & NS & $* *$ & NS & NS & NS \\
$\mathbf{1}$ & $* * * *$ & $* * * *$ & $* * * *$ & NS & - & NS & NS & NS & NS & NS & NS \\
$\mathbf{1 0}$ & $* * * *$ & $*$ & $*$ & NS & NS & - & NS & $*$ & NS & NS & NS \\
$\mathbf{1 5}$ & $* * * *$ & $* * * *$ & $* * * *$ & NS & NS & NS & - & NS & NS & NS & NS \\
$\mathbf{2 5}$ & $* * * *$ & $* * * *$ & $* * * *$ & $* *$ & NS & $*$ & NS & - & NS & NS & NS \\
$\mathbf{3 5}$ & $* * * *$ & $* *$ & $* *$ & NS & NS & NS & NS & NS & - & NS & NS \\
$\mathbf{5 0}$ & $* * * *$ & $* * * *$ & $* * * *$ & NS & NS & NS & NS & NS & NS & - & NS \\
$\mathbf{6 0}$ & $* * * *$ & $* * * *$ & $* * * *$ & NS & NS & NS & NS & NS & NS & NS & - \\
\hline
\end{tabular}

Fonte 1 - Autor da dissertação

$$
\text { NS = Não significativo } \quad \text { * Significativo }(P<0,05)
$$

$\mathrm{Na}$ análise de cálculo de área sob a curva das bandas de interesse, foi observada diferença estatística em todos os principais componentes orgânicos associados ao tecido ósseo: Amida I, Amida II, Amida III e Colágeno, quando comparados ao controle. As amidas estão diretamente relacionadas ao colágeno, que conforme a literatura é o componente mais abundante na matriz orgânica do tecido ósseo, que indica a degradação dos componentes orgânicos do tecido. Quando comparados entre si, os grupos irradiados seguiram um padrão, apresentando diferenças estatísticas até 10 kGy.

Na matriz orgânica do tecido ósseo observou-se que o tecido irradiado sofreu danos no colágeno, podendo diminuir sua proporção em até dois terços, a radiação ionizante também induz dano estrutural no DNA, inibindo a síntese do DNA, causa erros na síntese proteica, levando a morte celular. 50,51 
Em relação ao conteúdo inorgânico. A área da banda sob a curva do Fosfato v1,v3 $\mathrm{PO}_{4}^{3-}$ apresentou comportamento contrário ao do conteúdo orgânico, apresentando diferença estatística à partir dos grupos irradiados com doses acima de $10 \mathrm{kGy}$, indicando que a degradação do material orgânico do tecido, afetou a estrutura inorgânica, pois os materiais orgânicos associados ao tecido, são responsáveis pela sua resistência a tração e elasticidade. Esses efeitos podem prejudicar a formação óssea, em um experimento in-vivo, podendo causar diminuição na proliferação e diferenciação dos osteoblastos, induzindo a parada do ciclo celular, contribuindo na redução da densidade mineral óssea. 49 


\section{CONCLUSÕES}

A partir dos dados obtidos neste trabalho é possível afirmar que a radiação ionizante alterou a estrutura bioquímica do tecido ósseo, em sua matriz orgânica, independente da dose aplicada e inorgânica, a partir de 10 kGy..

A técnica de FTIR associada a técnicas de quimiometria foi capaz de identificar e diferenciar todos os grupos 
1 - J. C. REICHERTD. W. HUTMACHER. Bone Tissue Engineering. Tissue Engineering, Ed Springer, p.431-456, 2010.

2 - KAREN J.L. BURG, et.al. Biomaterial developments for bone tissue engineering. Biomaterials. vol 21, p.2347-2359, 2000.

3 - CARDEN, A. MORRIS,M. D. Application of vibrational spectroscopy to the study of mineralized tissues (review). Journal of Biomedical Optics, Vol 5,n. 3, p.259-268, 2000.

4 - INSTITUTO NACIONAL DE CANCER. Disponivel em <<http://www.inca.gov.br/estimativa/2016/index.asp?ID=2>> Acesso em 25/08/2017.

5 - THE ROYAL COLLEGE OF RADIOLOGISTS. Disponível em $<<$ https://www.rcr.ac.uk/system/files/publication/field_publication_files/bfco1 63_6_head_neck.pdf>> Acesso em: 25/08/2017.

6 - ASSOCIAÇÃO BRASILEIRA DE TRANSPLANTE DE ÓRGÃOS. Disponivel em:

<<http://www.abto.org.br/abtov03/default.aspx?mn=515\&c=900\&s=0\&friend $\mathrm{ly}=\mathrm{r}$ egistro-brasileiro-de-transplantes-estatistica-de-transplantes $>>$ Acesso em 25/08/2017.

7 - NGUYEN, H. MORGAN, D. A. F.; FORWOOD, M. R. Sterilization of allograft bone: effects of gamma irradiation on allograft biology and biomechanics. Cell and tissue banking, Vol. 8, n. 2, p. 93-105, 2007.

8- GIANNONI R.A., RODRIGUES O. Ressonância Paramagnética Eletrônica de Unhas Irradiadas: desafios para uma dosimetria em acidentes radiológicos. Instituto de Radioproteção e Dosimetria (IRD/CNEN-RJ); Instituto de Pesquisas Energéticas e Nucleares (IPEN/CNEN-SP). 10 Congresso Brasileiro de Metrologia das Radiações lonizantes, Rio de Janeiro/RJ, novembro de 2014.

9 - NOVO, E. M. L. de M. Sensoriamento Remoto: Princípios e Aplicações. Editora Edgar Blücher Itda. São José dos Campos, 1989. 308p.

10 - INDIANARA, S. Uma nova luz sobre o conceito de fóton: Para além de imagens esquizofrênicas. Revista Brasileira de Ensino de Física, vol 37 , n 4, p.4206-1-4206-8, 2015

11 - BAGNATO, V. PRATAVIEIRA, S. Luz para o progresso do conhecimento e suporte da vida. Revista Brasileira de Ensino de Física, vol 37, n 4, p 4204-1-4204-10, 2015 
12 - O Espectro Eletromagnético na Natureza, Disponivel em < http://labcisco.blogspot.com.br/2013/03/o-espectro-eletromagnetico-nanatureza.html> Acesso em: 27/08/2017

13- OLIVEIRA, A. MANO, JF. ROMÁN, JS. REIS, RL. Study of the influence of beta-radiation on the properties and mineralization of different starch-based biomaterials. Journal of biomedical materials research, $v$. 74 , n. 1, p. 560-9, 2005

14 - YOSHIMURA,E.M. Fisica das Radiações: interação da radiação com a matéria. Revista Brasileira de Física Médica, v. 3, n 1 p. 57-67, 2009.

15 - ANDRADE,B Medicina Nuclear, Disponivel em <http://slideplayer.com.br/slide/1876284> Acesso em: 22/08/2017.

16 - JONES, D.T.L. Present Status and Future Trends of Heavy Particle Radiotherapy in INTERNATIONAL CONFERENCE ON CYCLOTRONS AND THEIR APPLICATIONS, 35 th, June 14-19, Caen, France. Proceedings of the 15th International Conference on Cyclotrons and their Applications. South Africa: Medical Radiation Group. p. 13-20

17 - KOUKALAKA'S. Physics in Medicine Week 3: Radiotherapy.

Disponível em:< https://koukalaka.wordpress.com/2012/01/24/physics-inmedicine-week-3- radiotherapy/>. Acesso em: 27 nov. 2017.

18 - NOOUAILHETAS, Y. Radiações lonizantes e a vida. Disponível em: <http://www.cnen.gov.br/ensino/apostilas/rad_ion.pdf>.

19- MOHR H., SCHOPFER P. (1995) Effects of lonising Radiation. In: Plant Physiology. Springer, Berlin, Heidelberg.

20 - TAUHATA . L, et.al, RADIOPROTEÇÃO E DOSIMETRIA: FUNDAMENTOS. Disponivel em < http://www.ird.gov.br/index.php/component/jdownloads/send/36apostilas/105- radioprotecao-e-dosimetria-fundamentos-finali?option=com_jdownloads $>$ Acesso em 13/08/2017

21 - ANDO, R. A. Espectroscopia Vibracional, Raman Ressonante e Eletrônica de Nitroderivados em Sistemas Conjugados. s.l: s.n..

22- PAVIA, D. L.LAMPMAN.G.M. KRIZ. G.S. VYVYAN. J. R. Introdução à Espectroscopia. 4a Edição ed. São Paulo: Cengage Learning, 2010.

23 - AVERILL, B. et al, Principles of General Chemistry. Disponivel em < https://2012books.lardbucket.org/books/principles-of-general-chemistryv1.0/s13-01-predicting-the-geometry-of-mol.html> Acesso 15/12/2017

24 - GAROFF.S, LUOKKALA. B, Characterizing Molecular Vibrations Using Raman Spectroscopy, Disponivel em $<$ http://www- 
meg.phys.cmu.edu/physics_33340/experiments/mpl_raman.pdf $>>$ Acesso em28/08/2017.

25 - BARTZ, M. Evaluation of Microscopic Analytical Techniques for the Analysis of Artists' Materials, Disponivel em $<$ https://www.mccrone.com/mm/evaluation-microscopic-analyticaltechniques- analysis-artists-materials/> Acesso em 05/12/2017

26 - SILVERSTEIN, R. Identificação Espectrométrica de Compostos Orgânicos. 3 ed. Rio de Janeiro. Ed: Guanabara Dois S.A, 1979

27 - PIERSCINSKI, K. Time resolved FTIR study of spectral tuning and thermal dynamics of mid-IR QCLs.Spie Proceedings SPIE 9134, Semiconductor Lasers and Laser Dynamics VI, p. 91341L.

28 - SANTOS, M. Ablação De Pele Queimada Com Laser De Pulsos Ultra- Curtos Para Promoção Da Cicatrização. Avaliação Por Tomografia Por Coerencia Óptica, Histologia, Atr-Ftir E Microscopia Não Linear. 2012, 95p ,Tese Doutorado, Instituto de Pesquisas Energéticas e Nucleares

29 - FLORENCIO.S. R. SASSO. G. R. S. CERRI. E. S. SIMOES.M . S. CERRI. O. S. Biology of Bone Tissue : Structure, Function, and Factors That Influence Bone Cells.BioMed Research International v. 2015, p. 117, 2015.

30 - NETO, J. D. S. R. Hidroxiapatita Sintética Nanoestruturada e Esmalte Dental Aquecidos e Irradiados por LASER de Er,Cr:YSGG. Caracterização por FTIR e por DRX. 2009. 120 p. Dissertação (Mestrado em Tecnologia Nuclear) Instituto de Pesquisas Energéticas e Nucleares, São Paulo.

31 - VELOSO, M. N. Avaliação In Vitro dos efeitos da radiação ionizante em tecido ósseo Bovino por Epectroscopia ATR-FTIR e Análise Dinâmico- Mecânica.2013. 84 p. Dissertação (Mestrado em Tecnologia Nuclear) Instituto de Pesquisas Energéticas e Nucleares,São Paulo.

32 - WHITE, T. Apatite - An Adaptive Framework Structure. Reviews in Mineralogy and Geochemistry, v. 57, n. 1, p. 307-401, 2005.

33- BATISTA, T. M. Mineralização In Vitro de matrizes de colágeno aniônico derivadas de tecidos biológicos. 2008. 115p. Dissertação (Mestrado em Tecnologia Nuclear) Instituto de Pesquisas Energéticas e Nucleares,São Paulo.

34 - PASCHALIS, E. P., VERDELIS, K., DOTY, S. B., BOSKEY, A. L., MENDELSOHN, R. AND YAMAUCHI, M. (2001), Spectroscopic Characterization of Collagen Cross-Links in Bone. J Bone Miner Res, 16: 1821-1828. doi:10.1359/jbmr.2001.16.10.1821 
35- GOLDMAN, S., SMITH, L., GALARDY, P., PERKINS, S. L., FRAZER, J. K., SANGER, W., ANDERSON, J. R., GROSS, T. G., WEINSTEIN, H.,

HARRISON, L., SHIRAMIZU, B., BARTH, M. AND CAIRO, M. S. Rituximab with chemotherapy in children and adolescents with central nervous system and/or bone marrow-positive Burkitt lymphoma/leukaemia: a Children's Oncology Group Report. Br J Haematol, 167: 394-401. doi:10.1111/bjh.13040. 2014.

36 -FIGUEIREDO. M. M., GAMELAS. J. A. F. MARTINS. A. G. Characterization of Bone and Bone-Based Graft Materials Using FTIR Spectroscopy - Infrared Spectroscopy - Life and Biomedical Sciences . Disponivel em: $<$ http://cdn.intechopen.com/pdfs/36055/InTechCharacterization_of_bone_and_bone_based_graft_materials_using_ftir_sp ectro scopy.pdf $>>$ Acesso em: $30 / 05 / 2016$

37 - NOTINGHER. I, JELL. G., LOHBAUER.U., SALIH. V., HENCH. L., In Situ Non-Invasive Spectral Discrimination Between Bone Cell Phenotypes Used in Tissue Engineering, Journal of Cellular Biochemistry , v 92, p.1180-1992, 2004.

38 - FERNANDO, P, M. Placas ósseas confeccionadas a partir de diáfise cortical equina na osteossíntese femoral em coelhos.2010. 59 p. Dissertação (Mestrado em Ciencia Animal) Pontífica Universidade Católica do Paraná.

39 - COPSTEAD, L, E. et al. Perspectives on Pathophysiology, Purdue University, IPFW, 1995.

40 - PASCHALIS, E, P. et al. Infrared Assessment of Bone Quality, ClinicalOrthopaedics and Related Research. v 469, p 2170-2178, 2011

41 - FERREIRA, M, M, C. Quimiometria Conceitos, Métodos e Aplicações. Campinas: Unicamp, p. 110-153

42 - FISHER, R. A. (1936). The Use of Multiple Measurements in

TaxonomicProblems. Annals of Human Genetics. v 7 p: 179-188. 1936.

43 - . PEREIRA, L, F, S. ESPECTROSCOPIA NO NIR E PROCESSAMENTO DE IMAGENS DIGITAIS PARA CLASSSIFICAÇAO DE MAMAO PAPAIA (Carica papaya L.) GOLDEN. 2017. 80p.

Dissertação (Mestrado em Engengaria de Alimentos) Universidade Estadual de Campinas, Campinas.

44 - SOARES, L, F. et al. AVALIAÇÃO DE ESPECTRÔMETRO NIR PORTÁTIL E PLS-DA PARA A DISCRIMINAÇÃO DE SEIS ESPÉCIESSIMILARES DE MADEIRAS AMAZÔNICAS, Quimica Nova, v 40, p.418-428, 2017. 
45 - COSTA, G, B.. CLASSIFICAÇÃO MULTIVARIADA DE BIODIESEL B100 E B5 USANDO IMAGENS DIGITAIS. 2015. 80p. Dissertação (Mestrado emCiencias Agrarias) Universidade Estadual da Paraiba, Campina Grande.

46 - THOMPSON, T, J, U. et al. A new statistical approach for determining the crystallinity of heat-altered bone mineral from FTIR spectra, Journal of Acheological Science. V 40. p 416-422, 2013

47 - FARLAY,D. et al. Mineral maturity and crystallinity index are distinct characteristics of bone mineral. J Bone Miner Metab. v 28. p 433-445. 2010

48 - BOSKEY A, CAMACHO NP. FT-IR imaging of native and tissueengineered bone and cartilage. Biomaterials, v. 28, n. 15, p. 2465-2478, 2007

49 - WILLEY. J.S., LLOYD. S. A. J., NELSON. G. A., BATEMAN. T. A, lonizing Radiation and Bone Loss: Space Exploration and Clinical Therapy Applications, Clin Rev Bone Miner Metab, v.9, n. 1, p.54-62, 2011.

50 - BARTH, H. D. et al., Characterization of the effects of x-ray irradiation on the hierarchical structure and mechanical properties of human cortical bone. Biomaterials , v. 32, p.8892-890,2011

51 - SINGH. R, et al., Radiation sterilization of tissue allografts: A review, World Jornal of radiology, v. 8, n.4, p.355-369,2016 


\section{ANEXOS}

Carta do CEUA IPEN 120/13

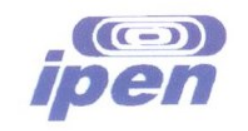

Comitê de Ética no Uso de Animais

Parecer - Projeto No 120/13 - CEUA-IPEN/SP

Com base nos pareceres apresentados pelos relatores, o protocolo de pesquisa "AVALIAÇÃO IN-VITRO DOS EFEITOS DA RADIAÇÃO IONIZANTE EM TECIDOS ÓSSEOS POR ESPECTROSCOPIA ATR -FTIR E ANALISE MECÂNICA DINÂMICA" de responsabilidade da pesquisadora Dra DENISE MARIA ZEZELL utilizará dentes bovinos coletados

frigorífico credenciado e portanto está ISENTO da avaliação pela CEUA.

São Paulo, 28 de agosto de 2013

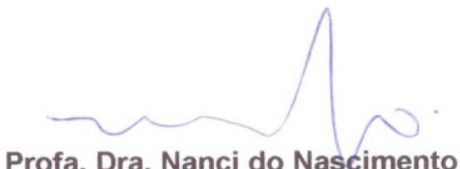

Profa. Dra. Nanci do Nascimento Coordenadora do CEUA-IPEN 
INSTITUTO DE PESQUISAS ENERGÉTICAS E NUCLEARES

Diretoria de Pesquisa, Desenvolvimento e Ensino

Av. Prof. Lineu Prestes, 2242 - Cidade Universitária CEP: 05508-000

Fone/Fax(0XX11) 3133-8908

SÃO PAULO - São Paulo - Brasil

http://www.ipen.br

O IPEN é uma Autaquia vinculada à Secretaria de Desenvolvimento, associada à Universiade de São Paulo e gerida técnica e administrativamente pela Comissão Nacional de Energia Nuclear, órgão do Ministério da Ciência, Tecnologia e Inovação. 